\title{
ROLLIN', ROLLIN', ROLLIN' ON THE RIVER: A STORY OF DROUGHT, TREATY INTERPRETATION, AND OTHER RIO GRANDE PROBLEMS \\ .1
}

\author{
Damien M. Schiff*
}

\section{INTRODUCTION}

Colonel Edward Hatch, Commander of the U.S. Ninth Cavalry, in his report to Congress detailing the actions he and his troops took to put down a disturbance that took place in late December of 1877 in the town of El Paso, Texas, over the attempted private appropriation of what theretofore had been public salt ponds, made the following observation:

As long as the frontier remains as it is now, and there is little probability of it changing, troubles of a like nature, or even more serious, are likely to occur. One which must be looked for sooner or later is in connection with the water taken from the Rio Grande for irrigation. As soon as the attempt is made to largely extend cultivation in this valley (there will not be enough water for all, and both sides have an equal right), from this troubles are certain to arise sooner or later, which may involve the two countries seriously.'

Colonel Hatch's prescience is remarkable, although few Americans today are aware of the serious water crisis now besetting the Rio Grande Basin of southern Texas and northern Mexico. The natural cause of this crisis is drought, its legal cause the "Treaty between the United States of America and Mexico respecting utilization of waters of the Colorado and Tijuana Rivers and of the Rio Grande."2 The problems posed by this dispute are more than

* B.A. magna cum laude, Georgetown University, 2000; J.D. University of San Diego School of Law, May 2004. I would like to thank Professor Jorge A. Vargas of the University of San Diego School of Law for suggesting this subject to me.

1. H.R. Ex. DOC. $45-85$, at 5-6 (1878).

2. Feb. 3, 1944, U.S.-Mex, 59 Stat. 1219 [hereinafter 1944 Water Treaty]. The souring relationship now developing between the two countries is masked by the usual diplomatic flatteries and conceits exemplified by the closing line of the State Department's Joint Communique issued after the signing of International Boundary and Water Commission (IBWC) Minute 308 in late June of 2002: "The work carried out . . . demonstrates-once again-the excellent atmosphere that exists in the cooperative relationship between the United States and Mexico." U.S. DEP'T OF STATE, JOINT COMMUNIQUE OF THE UNITED STATES AND MEXico CONCERning THE WATER PROBLem IN THE Rio GRANDE 2 (June 29, 2002), at http://www.ibwc.state.gov/PAO/CURPRESS/CurPress2/ jointcommuniquefinal.htm (last visited Aug. 12, 2002). But compare Ross E. Milloy, A Rift Over Rio Grande Water Rights, N.Y. 
academic. Scarcity of water in the Rio Grande Basin has produced serious economic consequences for both countries. The drought has cost Texas $\$ 175$ million in crop losses since $1996 .{ }^{3}$ In the Mexican state of Chihuahua alone, drought-related crop losses have cost the region 80,000 farm jobs. ${ }^{4}$ Exacerbating the meteorological crisis is a 1.37 million acre-feet ${ }^{5}$ debt that Mexico owes to the United States under a much maligned provision of the 1944 Water Treaty. The dispute over the treaty's interpretation could lead to the upset of a sixty-year old Rio Grande legal regime.

This Comment will analyze the 1944 Water Treaty and its subsequent developments, known as Minutes, to determine the legal standing of the signatory countries. Following that analysis, this Comment will discuss each side's position concerning the water debt and related provisions of the treaty. The argument herein is that the treaty ought to be retained because it is a proven framework through which the division and management of vital water resources have been made possible for the last half-century. But the retention of the treaty need not require the maintenance of the status quo. To the contrary, for the treaty to remain a fruitful basis for bi-national accord, the International Boundary and Water Commission (IBWC) must take up the charge of interpreting the treaty's provisions in a way that will preserve its essential purpose, viz. the equitable division of the waters of the Rio Grande and of the Colorado and Tijuana Rivers. This task must entail an extension of the time period within which Mexico is to pay its accrued water debt; a concerted effort by both sides substantially to reduce water waste caused by hydraulic infrastructure inefficiency; and the adoption of a plan to regulate expansion of beneficial uses in the Rio Grande Basin. The IBWC must nevertheless tread lightly, for any substantial move on its part, even with the approval of both countries' departments of state, may be tantamount to an amendment to the treaty, which would require ratification by the United States and Mexican Senates. That approval is by no means assured. If, however, the parties and the IBWC can steer an even course, with the aid of the aforementioned measures the current crisis will be resolved and the framework provided by the treaty itself will be preserved.

TimES, Sept. 18, 2001, at A14 (quoting a Texas local irrigation official: "We are upset, angry and scared. ... We've got farmers going out of business because Mexico has broken its promises on releasing water. That water is our lifeline, and they' re shutting it off."). See also Dudley Althaus, When Water Eludes Us All, HouSTON CHRONICLE, June 1, 2002, 2002 WL 3267505 (quoting a Mexican environmentalist: "What happens if this drought lasts three or four more years? ... It would mean the collapse of the state [of Chihuahua]. If it's the survival of the state versus the needs of 2,000 Texas farmers, you have to balance the costs.").

3. Richard Boudreaux, U.S., Mexico Reach Deal to End Water Dispute, L.A. TiMES, June 29,2002, at A5. Suffice it to say that this article's title represents a gross overstatement.

4. Chris Kraul, Fox Vows to Repay Mexican Water Debt to U.S., L.A. TiMES, May 16, 2002, at A3.

5. One acre-foot is the quantity of water required to cover an area of one acre to a depth of one foot. 


\section{THE 1944 TREATY}

\section{A. Historical Antecedents}

The 1944 Water Treaty was the natural offspring of over a century of river diplomacy between the United States and Mexico. On its face, the treaty purports to share equitably between the two countries the waters of the Rio Grande and of the Colorado and Tijuana Rivers. Much has changed in the region since the time of the treaty's ratification. ${ }^{6}$ Today, with the exception of San Diego, the border region consists of ten million persons living in fourteen sister-city pairs. ${ }^{7}$ The past sixty years have witnessed the creation of the maquiladora industry, which has brought great wealth and industrial development to the area. ${ }^{8}$ The Rio Grande Basin itself has been the site of tremendous population growth: a 400 percent increase since 1950 , spurred in part by NAFTA-related economic enrichment. ${ }^{9}$ These changes, coupled with a severe decade-long drought, have created a wedge dividing the two countries. To understand how the present dispute has come about, one must first look to the past and to the prior dealings of the two countries over their shared streams.

\section{Nineteenth-Century Treaties and Diplomacy}

The first treaty between the United States and Mexico that touched upon the Rio Grande was the 1848 Treaty of Guadalupe Hidalgo, ${ }^{10}$ commonly known as the instrument that ended the Mexican-American War. Article V of the treaty established the Rio Grande as the international boundary line dividing the two countries, but it is Article VII which proved to be a bone of contention between the treaty signatories in their subsequent water disputes. Article VII states that the Rio Grande, where it serves as the international boundary line, shall be open to the citizens of both countries for navigation, "and neither [country] shall, without the consent of the other, construct any

6. At the turn of the century, the city of Juarez amounted to 8,000 persons, El Paso to 16,000; today, Juarez has more than a million, El Paso 600,000. Albert E. Utton, Coping With Drought On An International River Under Stress: The Case of the Rio Grande/Rio Bravo, 39 NAT.RESOURCES J. 27, 32 (1999). In the lower Rio Grande Basin, the population of Monterrey, Mexico, has increased over 1,600 percent in the last one hundred years; that of Brownsville, Texas, by the same factor. Id. at 33 .

7. William A. Nitze, Meeting the Water Needs of the Border Region, POLICY PAPERS ON THE AMERICAS, Apr. 2002, at 6, at http://www.csis.org/americas/mexico/Nitze.pdf (last visited Nov. 12, 2003).

8. Id.

9. Hugh Dellios, Sharing the Rio Grande, CHI. TRIB., July 7, 2002, 2002 WL 2672875.

10. Treaty of Peace, Friendship, Limits, and Settlement with the Republic of Mexico, Feb. 2, 1848, U.S.-Mex., 9 Stat. 922 [hereinafter Treaty of Guadalupe Hidalgo]. 
work that may impede or interrupt, in whole or in part, the exercise of this right ...."11

Reaffirmed in part by the 1853 Gadsden Purchase, ${ }^{12}$ Article VII of the Treaty of Guadalupe Hidalgo was used by Mexico in the closing years of the nineteenth century to protest American development in the New Mexico portion of the Rio Grande Basin, especially the contemplated construction of the Elephant Butte Dam, which would substantially decrease the flow of the Rio Grande downstream and thereby reduce available water supplies to Mexican farmers and municipal residents. In 1889 the two sides took the first step toward resolving their differences by creating the International Boundary Commission (IBC), forerunner of the IBWC of the 1944 Water Treaty. ${ }^{13}$

The newly created IBC proved unable, however, to avoid a controversy over the American damming of the Rio Grande at Elephant Butte, New Mexico. Mexico contended that the United States was precluded by Article VII of the Treaty of Guadalupe Hidalgo from in any way impeding the navigability of the Rio Grande where it forms the international boundary; that actual and proposed American development had reduced the flow of the river; and, as a consequence, that its navigability was impaired. ${ }^{14}$ Perhaps because the argument was a too-thin mask for its real interest in a sufficient water supply from the Rio Grande, Mexico offered an argument based upon a distinct theory: as the uses of the Mexicans in the Rio Grande Basin were so much older than those of the Americans, the Mexican claims ought not to be prejudiced by the effects of the newer uses. ${ }^{15}$

11. Id. at 928 .

12. Treaty with Mexico, Dec. 30, 1853, U.S.-Mex., 10 Stat. 1031, 1034 [hereinafter Gadsden Purchase].

13. Convention between the United States of America and the United States of Mexico to facilitate the carrying out of the principles contained in the treaty of November 12,1884, and to avoid the difficulties occasioned by reason of the changes which take place in the bed of the Rio Grande and that of the Colorado River. Mar. 1, 1889, U.S.-Mex., 26 Stat. 1512, 1513 (extended indefinitely by the 1944 Water Treaty, supra note 2, at 1222).

14. James Simsarian, The Diversion of Waters Affecting the United States and Mexico, 17 TEX. L. REV. 27, 31-32 (1938).

15. Id. at 32. This argument represents a civil law version of the doctrine of "prior appropriation," defined in the seminal U.S. Supreme Court case of California v. Arizona, 238 U.S. 423, 459 (1931), as:

[T]o take and divert a specified quantity [of water] and put it to beneficial use in accordance with the laws of the State where such water is found, and, by so doing, to acquire under such laws, a vested right to take and divert from the same source, and to use and consume the same quantity of water annually forever, subject only to the right of prior appropriations.

The decision is germane to the present inquiry because it, and its equally important predecessor, Kansas v. Colorado, 206 U.S. 46 (1907), were treated by the American (and perhaps by the Mexican) negotiators to the 1944 Water Treaty as a tacit rejection of the Harmon Doctrine, which holds that an upper-riparian nation can utilize all of the flow of a river, regardless of the harm done by the decrease in available water to a lower-riparian nation. For the opinions of the American negotiators, see Hearings before the Committee on Foreign Relations United States Senate Seventy-Ninth Congress First Session on Treaty with Mexico Relating to the Utilization 
These arguments were rejected by the United States, based upon its theory of a state's absolute sovereignty and right of use over streams that flow through the state's territory, in spite of Mexico's counter argument that such

of the Waters of Certain Rivers, 79th Cong., 1st sess, at 98-100 (Jan. 1945) [hereinafter Hearings]. For an exposition of the Harmon Doctrine, see infra note 210.

The import of California $v$. Arizona cannot be fully grasped without first noting that the Court had already decided, in Kansas $v$. Colorado, that interstate water law disputes were appropriately adjudicated as between sovereigns. To reach that conclusion, the Court began with the premise that "each state has full jurisdiction over the lands within its borders, including the beds of streams and other waters," Kansas, 206 U.S. at 93, and the proposition that a state may choose whether to follow the traditional common law rule with respect to rivers or the one typically found in the sere climes of the western States. Id. at 94 . In either case, the Court will treat the states of the Union in this field as sovereigns, "[e]ach state [standing] on the same level with all the rest," so that their relations inter sese are governed by "equality of right." Id. at 97. The upshot of this language is that the Mexican position of the late 1890s-which we shall see remained basically the same up through the signing of the 1944 Water Treaty-was not far removed from the opinion of the Supreme Court in the same area of international law, a fact no doubt used by Mexico as a bargaining tool during the negotiations leading up to the 1944 Water Treaty.

It is interesting to note that the Court has continued to move toward the old Mexican position, which is based upon the principles of equitable use. The Court now disfavors the strict application of the prior appropriation doctrine as between states when it would deprive a state of all use of a watercourse's flow. In Colorado v. New Mexico, 459 U.S. 176, 178 (1982), the Court was faced with a New Mexico statute that had authorized the total appropriation of the Vermejo River. A strict application of the prior appropriation doctrine would have denied Colorado, the upper-riparian state, any diversion from the Vermejo. Id. at 180 . Rejecting New Mexico's argument that its senior use claims should be recognized unless doing so would endanger an "existing economy built upon junior appropriations," id. at 184, the Court held that the rule of prior appropriation should not be rigorously applied if the hardship thus placed upon the junior user would be greater than the benefit gained by the senior user. Id. at 186 . On remand to the special master, Colorado failed to prove by a clear and convincing standard that its proposed diversion of the Vermejo River would produce for it a benefit greater than the harm that would be done to New Mexico by the same diversion. Colorado v. New Mexico, 467 U.S. 310,321 (1984). Beyond the benefit-harm balancing test, the Court noted that, for a state to divert water for future uses under a theory of equitable apportionment, it was required to prove that the senior user could adopt reasonable conservation measures to ameliorate the effects of the proposed diversion by the junior user. Id. at 323-24.

The Court has for some time followed this doctrine of equitable apportionment in adjudicating interstate water disputes. The doctrine, designed to secure a just and equitable allocation of a river's flows, is applied by considering

physical and climactic conditions, the consumptive use of water in the several sections of the river, the character and rate of return flows, the extent of established uses, the availability of storage water, the practical effect of wasteful uses on downstream areas, [and] the damage to upstream areas as compared to the benefits to downstream areas if a limitation is imposed on the former.

Nebraska v. Wyoming, 325 U.S. 589, 618 (1945) (decided in the same year as ratification of 1944 Water Treaty). The foregoing list is not exhaustive of the factors taken into account, although prior uses will be given great weight when the balancing is done.

Given that the Supreme Court has adopted a riparian jurisprudence very similar to that espoused by Mexico in the years leading up to the negotiation of the 1944 Water Treaty, should any dispute over the treaty's provisions find its way before an international tribunal, Mexico could undoubtedly use the U.S. Supreme Court's adoption of the Mexican position in arguing its case. 
a position was inappropriate for an international watercourse like the Rio Grande. ${ }^{16}$ The dispute came to the forefront in the early part of the twentieth century, and saw its temporary resolution in the 1906 Rio Grande Convention. $^{17}$

\section{The 1906 Rio Grande Convention}

The terms of the 1906 Rio Grande Convention are simple and straightforward. Article I requires the United States to deliver to Mexico, at the completion of the Elephant Butte Dam along the Rio Grande in New Mexico, an annual quantity of 60,000 acre-feet of water, ${ }^{18}$ and to pay for all the costs involved in the annual transport of water to Mexico. ${ }^{19}$ Especially important is Article II, which states that, in the event of "extraordinary drought or serious accident to the irrigation system in the United States, the amount delivered to Mexico shall be diminished in the same proportion as the water delivered to lands [from the Elephant Butte Reservoir] in the United States."20 This phrase is substantially similar to that found in Article 10 of the 1944 Water Treaty, which permits the United States to reduce deliveries of water from the Colorado River to Mexico. ${ }^{21}$ In fact, American negotiators to the 1944 Water Treaty used the language of Article II of the 1906 Rio Grande Convention as the basis for the "extraordinary drought" provisions of the later document. $^{22}$ Emphasizing the purportedly ad hoc nature of the agreement, Article $\mathrm{V}$ makes clear that the convention would have no precedential value and could not be construed by either party as a definitive acknowledgment by the United States of some principle of international law governing the division of the waters of shared streams. ${ }^{23}$ This valuable provision avoided tying the hands of American negotiators in the bargaining sessions leading up to the signing of the 1944 Water Treaty. For this and other reasons, the convention has been lambasted by Mexican commentators. ${ }^{24}$ It was, then, in a somewhat

16. Simsarian, supra note 14 , at 32 .

17. Convention With Mexico Providing for the Equitable Distribution of the Waters of the Rio Grande for Irrigation Purposes, May 21, 1906, U.S.-Mex., 34 Stat. 2953 [hereinafter 1906 Rio Grande Convention].

18. Id. at 2954.

19. Id.

20. Id.

21. 1944 Water Treaty, supra note 2, at 1237-38. See also infra Part II.B.

22. See Charles J. Meyers \& Richard L. Noble, The Colorado River: The Treaty With Mexico, 19 STAN. L. REV. 367, 411-15 (1966-67). See also Hearings, supra note 15, at 92-93. "As I say, that particular provision was patterned after a similar one that is to be found in the treaty of 1906 with Mexico, and we experienced no difficulty with that." Statement of Frank B. Clayton, Counsel, American Section, International Boundary Commission, cited in Meyers \& Noble, supra, at 411 n.202.

23. 1906 Rio Grande Convention, supra note 17, at 2955.

24. The Mexican complaint stems from the alleged difference in meaning between the English and Spanish versions of the convention. In Article IV of the same, the English version uses the phrase "of any claim" in reference to the extent of the Mexican renunciation of future 
unfriendly and strained environment that negotiations leading to the 1944 Water Treaty commenced.

\section{The Making of the 1944 Water Treaty}

Following the triumph (or fracas) of the 1906 Rio Grande Convention, little effort was made toward negotiating a comprehensive water treaty until the late 1920s, at which time the American and Mexican sections of the International Water Commission ${ }^{25}$ began formal talks with the aim of negotiating a solution. ${ }^{26}$ Their hopes were soon dashed when a series of impasses arose during discussions. To begin with, Mexico asked for an annual Colorado

grounds of protest; the Spanish version reads "derecho" for "claim." Wherever else the word "claim" is used in Article IV or V, the Spanish word used is "reclamacion." The American drafters of the convention were from the eastern U.S. and, being unfamiliar with the niceties of water law jargon, used the word "claim" to mean both water right and legal right. Mexican negotiators understood "reclamacion" in the traditional sense, i.e. the right of prior appropriation. It was this right only that Mexico was willing to give up; it did not intend to forfeit its "derecho based on current Treaties and the norms of International Law; and, in any event, the Spanish language does not have words to express the foreign legal terms of the appropriation doctrine, instead needing to supplement them with short phrases in conformity with the meaning of each sentence." 1 ERNESTO ENRIQUEZ COYRO, EL TRATADO ENTRE MÉXICO Y LOS ESTADOS UNIDOS DE AMÉRICA SOBRE RÍOS INTERNACIONALES 253 (1975).

Coyro's argument is that Mexico did intend to give up any additional future claim to the annual 60,000 acre-feet entitlement it received under the convention, but it had no intention of putting to rest its earlier claims (derechos) based upon the Treaty of Guadalupe Hidalgo and international law in general. Id. The use of the word "reclamacion" conjured in Mexican minds the doctrine of prior appropriation; the English equivalent in the convention, viz. claim, was interpreted by the Americans in its traditional - but not Mexican-sense of a right enforceable in a court of law. Id. Coyro quotes from a letter of Mexican Ambassador to the U.S. Joaquín Casasús, who represented Mexico during the convention's negotiation, wherein Casasús claims that

the purpose of the Treaty is to give us [Mexico] the water we have claimed, without having to declare we have had a right to it, because then it would admit that they [the U.S.] have had no reason or motive for the prolonged discussions over the subject.

Id. at 260. Coyro concludes that the 1906 Rio Grande Convention was "an injury for Mexico in light of current Treaties and International Law; for the U.S.A., the success of an imposition of its power." Id. at 266.

During the Senate ratification hearings for the 1944 Water Treaty, the American Commissioner of the International Boundary Commission, L.M. Lawson, described the Mexican position in 1906 as "the principle whereby established beneficial uses of water are deemed entitled to protection against encroachment resulting from upstream diversions." Hearings, supra note 15 , at 23 . He added that the same principle was applied in calculating the Rio Grande and Colorado River allotments made under the 1944 Water Treaty. Id. But when asked by Senator Downey of California whether it was true that, prior to the 1906 Rio Grande Convention, Mexico had "direct-flow rights in the Rio Grande of 60,000 acre-feet," Lawson pithily replied "[s] he may have had the rights, but she did not have the water." Id. at 42.

25. The International Water Commission is an ad hoc committee consisting of American and Mexican representatives whose powers and privileges were eventually transferred to the International Boundary Commission.

26. Charles A. Timm, 10 DEPT. OF STATE BULL. 282, 285 (1944). 
River allotment of 4.5 million acre-feet; the United States was willing to go only so far as 750,000 acre-feet. ${ }^{27}$ The Mexican and American sections also disagreed as to the precedential value that ought to be accorded the 1906 Rio Grande Convention. ${ }^{28}$ Lastly, the two sides strongly disagreed over the proper division of the waters of the Rio Grande: the U.S. section wished to have current uses protected, ${ }^{29}$ while the Mexican section demanded that all waters reaching the main channel of the Rio Grande be shared equally between the two countries. ${ }^{30}$

A related stumbling block to these negotiations was whether Mexico would guarantee the perpetuation of the Texas agricultural projects south of Fort Quitman. ${ }^{31}$ In that part of the Rio Grande, seventy percent of the river's inflows come from the Mexican tributaries of the Rio Conchos and San Juan River, ${ }^{32}$ but Texas farmers would be the ones relying most upon the Rio Grande's flows in that segment. ${ }^{33}$ As aforementioned, Mexico wished to allow each country to exploit fully its own tributaries and then merely to divide equally between each other the flows that reached the Rio Grande. ${ }^{34}$

Although the two countries maintained a discussion of the water dispute through diplomatic communiques, ${ }^{35}$ the immediate impetus for the recommencing of negotiations leading to the ratification of the treaty was the

27. H.R. Doc 71-359, at 5 (1930).

28. Id. Point I (a) of the statement of the Mexican Section of September 2, 1929, in regard to the 1906 agreement, claimed that "it was not the main purpose of this convention to settle the problems of the waters between the two countries, notwithstanding that it so states." Id. at 6 .

29. "The American section feels that a treaty should be entered into between the United States and Mexico whereby existing uses that have grown up in either country for the waters of the Rio Grande would be recognized and perpetuated...." Id. at 28.

30. Id. at 61. The Mexican section wanted no restriction on Mexico's use of its Rio Grande tributaries and justified its position with what can best be termed as the Mexican variant of the Harmon Doctrine: "The Mexican section stated that it could not agree to this or to any restriction on the complete sovereignty of Mexico and its right to use all of the water of its tributaries to the Rio Grande ...." Id. at 14.

31. Timm, supra note 26.

32. Id. at 285 .

33. Id.

34. Id.

35. In a letter dated December 27, 1939, Under Secretary of State Welles suggested to the Mexican Ambassador to the U.S. Castillo Najera that a solution could be reached by having Mexico give the United States $X$ amount of water from the Rio Grande and by having the United States give Mexico $X$ amount of water from the Colorado River. 5 FOREIGN RELATIONS OFTHE U.S. 1029 (1940). Castillo Najera first responded that Mexico would prefer an agreement covering both present and future uses of the two streams. Id. at 1031. Later, in a memorandum dated February 5, 1940, the Ambassador became ugly, first alleging that the Rio Grande problem was due to "immoderate American uses thereof," id. at 1033, and then making what can only be termed a thinly veiled threat in reference to proposed American developments that would be dependent upon the water of the Rio Grande: "if Mexico should in the future, as must sooner or later happen, utilize those waters, there would be danger that, in the end, the works completed by the United States would be useless." Id. at 1033-34 (emphasis added). The United States was thereby put on notice that Mexico would be no pushover in subsequent treaty negotiations. 
assembling by the U.S. Department of State of what came to be known as the "Committee of Fourteen," comprised of two representatives from each of the seven Colorado River Basin states, and the "Committee of Sixteen," comprised of the members of the Committee of Fourteen and two representatives from the hydroelectric power interests of the Colorado River. ${ }^{36}$ At an April 1943 meeting of these committees and State Department officials, a resolution was adopted detailing the guideposts to be followed in future treaty negotiations with Mexico. ${ }^{37}$ Talks with Mexico were conducted on the basis of this resolution; emerging from these discussions was the 1944 Water Treaty, whose terms resolved the earlier impasse of the Texas agricultural developments by guaranteeing them a minimum annual quantity of Rio Grande water. ${ }^{38}$

The settling of the division of Rio Grande waters was only part of the task of the treaty's negotiators; a separate analysis of the Colorado River was also required. Indeed, in many respects, the Colorado River is the exegetical key to understanding the water-sharing provisions of the 1944 Water Treaty taken in toto. During negotiations, Mexico had asked for an annual allotment of 3.6 million acre-feet of water, with the United States making a counteroffer of 750,000 acre-feet (equaling Mexico's peak consumption of Colorado River water up to that point in history).$^{39}$ Mexico was able to win its treaty water allotment of 1.5 million acre-feet, despite fierce opposition from the lower Colorado River Basin states, because of the fear in the minds of American negotiators that, by holding out, Mexico could win a far more favorable award

36. Timm, supra note 26 , at 288 .

37. Id.

38. 1944 Water Treaty, supra note 2 , at 1226-27. The simplest explanation for this concession is that, in exchange for the annual Rio Grande guarantee, Mexico obtained a guarantee for Colorado River water greater than it otherwise would have received. For a contrary view, see the reply of L.M. Lawson, American Commissioner of the International Boundary Commission, to Senator Downey of California's question concerning the same issue:

I can say that at no time was there the question of trading waters between the two countries or the question of the amount that might be used in a trade between the two countries. The settlement was entirely on the basis of each stream system. There is no connection in amounts, there is no connection in physical situation or geography, that would have any connection between the two rivers.

Hearings, supra note 15, at 34. And yet, Senator Hayden of Texas, speaking in reference to the Boulder Canyon Project Act, discussed infra note 42, was of the opinion that the allotments from the two rivers ought to have been considered together:

The reason why the Texas delegation [to the House of Representatives] urged and voted for the passage of the Boulder Canyon project was an assurance to them from the California delegation that if the Boulder Dam was built it would enable more water to be given to Texas ....

$\cdots$

[I] $\mathrm{t}$ was understood at the time that in consideration of the Boulder Canyon project, Texas would benefit by an arrangement with Mexico.

Hearings, supra note 15 , at $33-34$.

39. Timm, supra note 26 , at 287 . Note the reduction from the 1929 offer, see text accompanying supra note 27 , by about one million acre-feet in the Mexican request. 
under the provisions of a 1929 inter-American arbitration treaty, to which the United States and Mexico were parties. ${ }^{40}$ The main opposition to ratification of the 1944 Water Treaty came from California, which did not want its

40. Inter-American Arbitration Treaty between the United States of America and other American Republics, Jan. 5, 1929, 46 Stat. 3153 [hereinafter Arbitration Treaty]. The purpose of the treaty was to "adopt obligatory arbitration as the means for the settlement of [the signatories'] international differences of a juridical character." Id. at 3154. It is clear from the 1944 Water Treaty Senate ratification hearings that the proponents of the treaty believed Mexico could obtain, under the Arbitration Treaty, an award for Colorado River water far better than what it received under the 1944 Water Treaty. See, e.g., the statement of Jean S. Breitenstein, attorney and representative for six of the seven Colorado River Basin states (California not included): "Of course, as many have commented, there may be voluntary arbitration. It is my opinion that there may also be compulsory arbitration under the 1929 treaty." Hearings, supra note 15, at 1539 . And later, "So, I say that if we should come to arbitration on this matter in 10,20 , or 50 years, the equities would be weighed as they then existed," $i d$. at 1541 , meaning that Mexico could have declined to sign the treaty, proceeded to develop beneficial uses to the water then flowing through its territory from the Colorado River (which exceeded 1.5 million acre-feet per year), and sought an arbitration award protecting those expanded uses. See the opinion of Fred Wilson, attorney for the New Mexico Interstate Streams Commission, as to why the ratification of the 1944 Water Treaty was imperative:

[I]n view of the fact that the engineers agree that at the present time about 9,000,000 acre-feet of water per annum passes the boundary into Mexico and will continue to do so for many years to come, Mexico's uses will rapidly expand, and may well ultimately reach in excess of 5,000,000 acre-feet per annum. Thus, her position in any arbitration proceeding in the future or in any future treaty negotiations would be much more advantageous than at the present time.

Id. at 1583. When asked during the hearings whether he thought the Arbitration Treaty would apply to the Colorado River, Clifford Stone, director of the Colorado Water Conservation Board, responded:

We consulted with lawyers who have had experience in those matters, and we made a study of the treaty, and the conclusion seemed inescapable to us that the 1929 arbitration treaty did apply to this situation and that Mexico could come within the terms of that arbitration treaty in asking for an adjustment of this problem.

Id. at 1443. After hinting that the arbitration panel would not contain a majority friendly to American interests, Senator Connolly of Texas, chairman of the Foreign Relations Committee, stated frankly, "I am very definitely of the opinion that if we do not get a treaty of some kind, if I were a Mexican citizen I would certainly insist on an arbitration of this matter." Id.

A review of the Arbitration Treaty supports the opinion that the subject matter of the 1944 Water Treaty could have been brought to binding arbitration. Article 1 of the treaty stated that the parties would submit their differences to arbitration when "it has not been possible to adjust [them] by diplomacy and which are juridical in their nature ...." Arbitration Treaty, supra, at 3158. Article 1(b) defines a juridical question as including "[a]ny question of international law." Id. Under such a broad formulation, it would be an easy task to consider the division of the waters of the Rio Grande and Colorado River a juridical question subject to binding arbitration. As for Senator Connolly's insinuation that the arbitration panel might be biased against U.S. interests, Article 3 of the treaty required the parties to arbitration each to pick two arbitrators, one of whom could not be a national of the nominating party; once done, the four nominees would select a fifth arbitrator. Id. at 3160 . Probably, then, the arbitration panel would not have contained a majority of American citizens - perhaps merely one. Senator Connolly's assessment of U.S. prospects under the Arbitration Treaty does not appear off the mark. 
Colorado River allotment under the Boulder Canyon Project $\mathrm{Act}^{41}$ reduced because of concessions in allotments due Mexico. ${ }^{42}$ Although the opposition was defeated and the treaty ratified, the basis for the original objection to the treaty has not disappeared. ${ }^{43}$

From the foregoing one may safely conclude that Mexico was not without bargaining power in negotiating the 1944 Water Treaty; it could play Rio Grande parties, desirous of a treaty, against California, ardently opposed to any allotment that might threaten its own Colorado entitlements; it had the ace in the hole of the 1929 Arbitration Treaty, ${ }^{44}$ which portended a settlement far more favorable to Mexico than any it would otherwise receive from the United States; and it could reap the benefits from a United States less anxious than before to assert its rights under a theory of absolute territorial sovereignty over the flow of international streams. ${ }^{45}$ Having established some sense of the historical backdrop of the 1944 Water Treaty, it is time to turn now to its provisions.

\section{B. The 1944 Water Treaty's Provisions}

The 1944 Water Treaty purports to create a legal regime able to govern all potential uses of the waters of the Colorado and Tijuana Rivers and of the Rio Grande. ${ }^{46}$ For the purposes of this Comment, the most important sections

\section{45 Stat. 1057 (1928).}

42. The Boulder Canyon Project Act, id, had affirmed the earlier Colorado River Compact, which divided the waters of that River among the seven basin states. Under the agreements, California was to receive an allotment of 4.4 million acre-feet per year, which would not be reduced unless it should "become necessary to supply water to the United States of Mexico from waters over and above the quantities which are surplus as defined by said compact, then the State of California shall and will mutually agree with the State of Arizona to supply, out of the main stream of the Colorado River, one-half of any deficiency which must be supplied to Mexico by the lower basin ...." Id. at 1059. Therefore, the smaller the Colorado River concession in any water-sharing treaty with Mexico, the more secure California's water supply would be, and hence the state's opposition to the 1944 Water Treaty's Article 10 allotment of 1.5 million acre-feet per year to Mexico.

43. See Meyers \& Noble, supra note 22, at 411-15 (disputing the claim that the "extraordinary drought" clause of Article 10 is an effective protection for Colorado River Basin states' interests in the case of drought, mainly because the treaty language comes with no interpretative guidelines: "All told, it seems extremely unlikely that the United States can, as a practical matter, ever expect to rely on article 10 to reduce deliveries to Mexico.'). Id. at 415.

44. See the comments of Senator Connolly of Texas, quoted supra note 40.

45. "It must be realized that each country owes to the other some obligation with respect to the waters of these international streams ...." Hearings, supra note 15, at 19 (statement of Edward R. Stettinius, Jr., Secretary of State).

46. Some commentators have claimed that one of the major shortcomings of the 1944 Water Treaty is its failure to take into account what are now considered to be beneficial uses of water, but which were not so considered at the time of the treaty's ratification, e.g. ecological uses, Native American claims, and groundwater. See, e.g., Stephen P. Mumme, Reinventing the International Boundary and Water Commission, BORDERLINES, July 2001, at 6, at http://www .us-mex.org/borderlines/bkissues.html (last visited Jan. 7, 2003). Article 3(7) of the treaty states that the IBWC may consider "[a]ny other beneficial uses which may be determined by the 
of the treaty are: Article 4, dealing with the allocation of the waters of the Rio Grande; Articles 10 through 15, dealing with the allocation of the waters of the Colorado River; and Article 24, containing the enumeration of IBWC powers and privileges vis à vis the treaty's interpretation and application, as well as the grant of authority to the IBWC to resolve disputes arising under the treaty. ${ }^{47}$ Article 4(A) allots to Mexico:
(a) all of the waters reaching the Rio Grande from the San Juan and Alamo Rivers; (b) one-half of the main channel flow below the lowest, i.e. farthest downstream, international

Commission." 1944 Water Treaty, supra note 2, at 1225 . The power conferred presumably would enable the IBWC to adapt to changed circumstances. But see Stephen Mumme, The Case For Adding An Ecology Minute To The 1944 United States-Mexico Water Treaty, 15 TUL. ENVTL. L.J. 239 (2002) (arguing that the treaty's article 3 preferential listing precludes explicitly giving priority to ecological uses of water, and so urging that the IBWC use its flood control power to "contribute to Delta ecosystem management by means of the creative use of drainage related, ostensibly, to flood control." Id. at 252).

The IBWC has recently evinced a willingness to wade into the waters of environmental issues in the border region. Minute 306: Conceptual Framework for United States-Mexico Studies for Future Recommendations Concerning the Riparian and Estuarine Ecology of the Limitrophe Section of the Colorado River and its Associated Delta, Dec. 12, 2000, U.S.-Mex, at http://www.ibwc.state.gov/html/foreign_affairs.html (last visited Apr. 30, 2003) [hereinafter Minute 306], is a good example of the interest the IBWC now shows in ecological matters falling within its treaty mandate. Recommendation 1 requires the IBWC to establish "a framework for cooperation ... to ensure use of water for ecological purposes." Id. at 2 . Point 2 provides for a technical task force to define the "habitat needs of fish, and marine and wildlife species of concern to each country" in the Colorado River Delta. Id. Lastly, Point 3 creates a forum for the exchange of information concerning Delta ecology. Id. Minute 306, however, represents the practical limits of the IBWC's liberal interpretation of the 1944 Water Treaty's Article 3(7) beneficial uses clause, for both countries have chosen to address border ecology problems through other routes, e.g. the Agreement between the United States of America and the United Mexican States on Cooperation for the Protection and Improvement of the Environment in the Border Area. Aug. 14, 1983, U.S.-Mex., 35 U.S.T. 2916 (popularly known as the La Paz Agreement). Article 9 of the same requires each country to designate a national coordinator to implement the Agreement's various mandates; for the United States, this coordinator is the Environmental Protection Agency. Id. at 2919-20. The last clause of Article 12 states that "[n]othing in this Agreement shall prejudice or otherwise affect the functions entrusted to the International Boundary and Water Commission, in accordance with the Water Treaty of 1944." Id. at 2921. The import of Articles 9 and 12 is clear: the IBWC has some say in the handling of environmental problems occurring within the border region, but its authority is by no means exhaustive or exclusive, or even substantial. Given this limitation, the efforts made hitherto by the IBWC ought in fairness to be considered more than merely token.

47. The limits of this Comment preclude an exhaustive resumé; however, mention should be made of other salient portions of the treaty. Article 3 lists examples of beneficial water uses that the IBWC may follow. 1944 Water Treaty, supra note 2, at 1225. Article 5 lays the groundwork for the construction of international storage dams along the Rio Grande (Amistad and Falcon Dams are the fruit of this provision). Id. at 1228-30. Article 16 concerns the Tijuana River Valley. Id. at 1249-50. Lastly, the Senate, through its advice and consent, appended several provisions to the treaty that became a part of the same upon ratification. These amendments concern Congress's assertion of the power of the purse for monies spent on construction projects approved by the treaty or the IBWC and the procedures for confirmation of certain IBWC officials. Id. at 1263-66. 
storage reservoir; (c) two-thirds of the flow reaching the main channel from the Conchos, San Diego, San Rodrigo, Escondido, and Salado Rivers and Las Vacas Arroyo; and (d) one-half of all other unmeasured flows reaching the main channel. ${ }^{48}$ Article 4(B) allots to the U.S.: (a) all of the waters reaching the main channel from the Pecos and Devils Rivers, the Goodenough Spring, and the Alamito, Terlingua, San Felipe, and Pinto Creeks; (b) one-half of the waters flowing below the lowest major international storage dam; (c) onethird of the waters reaching the Rio Grande from the Conchos, San Diego, San Rodrigo, Escondido, and Salado Rivers and Las Vacas Arroyo; and (d) one half of all other flows in the main channel not otherwise accounted for. ${ }^{49}$

From a superficial review of the treaty's provisions, it appears that both Mexico and the United States can each fully exploit two tributaries (a nod to the Mexican bargaining position); both Mexico and the United States receive an equal share of unmeasured inflows; and the United States is guaranteed one-third of the inflow from six Mexican tributaries to ensure an adequate water supply for its southern Texas agricultural industry (an apparent concession by Mexico). ${ }^{50}$ The ultimate source of the current controversy lies not in these allocation provisions, but in the guarantee clause of Article 4(B)(c). That provision states that the one-third flow allotted to the United States from the aforementioned six Mexican tributaries "shall not be less, as an average amount in cycles of five consecutive years, than 350,000 acre-feet . . . annually." 51 This clause represents the greatest bargaining coup the United States achieved in negotiating the treaty. ${ }^{52}$ By it, Mexico is handed an immoveable obstacle to its complete exploitation of its six tributaries: regardless of how much water actually flows into the Rio Grande from the named tributaries, the United States remains entitled to a yearly average of no less than 350,000 acre-feet. ${ }^{53}$ The same clause permits Mexico, in the case of

48. 1944 Water Treaty, supra note 2, at 1225-26.

49. Id. at 1226-27.

50. See supra note 30.

51. 1944 Water Treaty, supra note 2, at 1226-27.

52. See the statement of Frank B. Clayton, counsel to the American Section of the IBC: "We want a commitment to deliver on the Rio Grande the same quantity of water that the treaty provides for and not to make us subject to a unilateral increase on [Mexico's] part, on either river." Hearings, supra note 15 , at 123.

53. In the current controversy, Mexico had claimed that it was not legally obligated to pay its current water debt until the conclusion of the five-year accounting period. Boudreaux, supra note 3 . This position makes sense given that the 350,000 acre-foot figure is not an entitlement per se but merely a baseline to be compared with an average over five years of actual Mexican contributions. Technically, Mexico cannot be in debt simply because it has fallen behind a preferred schedule of water transfers, as a hypothesi a five-year average cannot be calculated 
"extreme drought or serious accident to the hydraulic systems on the measured Mexican tributaries," to add any debt incurred during a five-year cycle to the following accounting period..$^{54}$ The clause in no way reduces Mexico's water debt; it simply buys another five years for Mexico to meet its obligation. Moreover, the clause says nothing about what is to be done when Mexico incurs water debts under two successive accounting periods. The treaty deems Mexico's debt to be liquidated when at least two major international reservoirs are filled with waters belonging to the United States. ${ }^{55}$

No analysis of the 1944 Water Treaty's allotment provisions would be complete without a review of the articles dealing with the Colorado River; the fairness or inequity of the treaty's water allocation can only be fairly judged when both the Rio Grande and Colorado River are considered together. Article 10(a) allots to Mexico a "guaranteed annual quantity of 1,500,000 acre-feet." 56 Subparagraph (b) also allots to Mexico any remaining water that reaches Mexico from the Rio Grande, provided that the U.S. obligation never exceeds $1,700,000$ acre-feet per year. ${ }^{57}$ Using almost identical language to that found in Article 4(B)(c), Article 10 concludes by allowing the United States, in cases of "extraordinary drought or serious accident to the irrigation system in the United States," to reduce its 1,500,000 acre-feet per year obligation to Mexico in proportion with the degree to which U.S. consumptive uses have been reduced. ${ }^{58}$ Unlike Mexico's Rio Grande obligation, the United States is required to furnish Mexico with water on a yearly basis without benefit of multi-year accounting periods and without the option of adding a water debt incurred during one year onto the following year's obligation. ${ }^{59}$ In place of these protections, the United States is afforded the option of reducing its treaty obligation to Mexico to the extent that the precipitating cause of the water shortage has reduced water consumption throughout the Colorado River Basin. ${ }^{60}$ The disparity in the drought provisions for the Colorado River and Rio Grande under the treaty creates the appearance of inequity; but, the Mexican response, both official and unofficial, to the present water crisis has been, essentially, that the region is naturally arid, that it is beset by drought,

until five years have passed. But now the question is moot, as Mexico has incurred a debt extending over two five-year cycles.

54. 1944 Water Treaty, supra note 2 , at 1227.

55. Id. at 1227-28. Mexico may liquidate its debt by furnishing sufficient inflows to the main channel from the measured tributaries to surpass the 350,000 acre-feet per year average, i.e. the foregoing does not exhaust Mexico's debt-payment options. Nonetheless, if one-third of the inflows from the measured tributaries were greater than the five-year average exceeding 350,000 acre-feet, the U.S. would be entitled to the larger quantity.

56. Id. at 1237.

57. Id.

58. Id. at 1237-38. For the source of the "extraordinary drought" language, see supra note 22.

59. 1944 Water Treaty, supra note 2 , at 1237.

60. Id. at $1237-38$. 
and, consequently, that there is an insufficient supply of water to satisfy all demands on both sides of the border. ${ }^{61}$

The drafters of the treaty presumably were aware that disputes would arise as to the proper interpretation and application of the treaty's provisions, especially those relating to water debts. Accordingly, Article 24 stands as the empowering instrument for the IBWC to serve as the first and ordinarily final arbiter of disputes arising under the treaty. Subparagraph (c) entrusts the IBWC with supervisory powers. ${ }^{62}$ Subparagraph (d) mandates that the IBWC "settle all differences that may arise between the two Governments with respect to the interpretation of this Treaty, subject to the approval of the two Governments." ${ }^{63}$ When matters are presented to the IBWC for their resolution, the Commission issues its decisions in the form of Minutes. ${ }^{64}$

61. "This is a dry region, ours. We've known it for 1,000 years" (statement of Alvaro Rivera Fernandez, head of Tamaulipas farmers union). Dellios, supra note 9. "It's not raining; that's the fundamental problem" (statement of Monserrat Terrazas, general director of a farmers irrigation association in Delicias, Chihuahua). Althaus, supra note 2. "We can't pay [the debt] off, we don't have the water" (statement of Enrique Martinez, governor of Coahuila). Tim Weiner, Water Crisis Grows Into a Test of U.S.-Mexico Relations, N.Y. TIMES, May 24, 2002, at A3. "We don't have any water... The harsh truth is that drought is a fact of life in northern Mexico and the southwestern United States." (statement of Patricio Martinez, governor of Chihuahua). Id. "The water the U.S. is demanding doesn't exist." (statement of Silvia Hernandez, head of the Mexican Senate committee on North American relations). Id.

62. 1944 Water Treaty, supra note 2 , at $\mathbf{1 2 5 6 .}$

63. Id. The provision goes on to require that, whenever the IBWC commissioners fail to resolve a contested matter, the dispute is to be referred to the two Governments for its resolution; the mode of resolution is "where proper ... the general or special agreements which the two Governments have concluded for the settlement of controversies." Id. As will be shown, both sides have interpreted that language to allow recourse to the International Court of Justice. See Herbert Brownell \& Samuel D. Eaton, The Colorado River Salinity Problem with Mexico, 69 AMER. J. INT'LL. 255, 259 (1975). U.S. action during the current controversy clearly shows its desire to resolve the dispute through the IBWC without recourse to independent bodies.

64. 1944 Water Treaty, supra note 2, at 1258. For a Minute to take effect, it must be approved by both Governments within thirty days of the Minute's presentation to the Governments. Id. Article 2 provides that whenever "joint action or joint agreement by the two Governments" is called for, the matter is to be handled through the U.S. Department of State and the Mexican Ministry of Foreign Relations. Id. at 1223. It is clear from the tenor of Articles 2, 24, and 25, that once approved, the IBWC Minutes become binding upon the two countries. This is so even though the U.S. Senate need not give its advice and consent for approval of the Minutes. The Senate did see fit prior to ratifying the treaty to add several provisions ensuring that the Congress would have, inter alia, the power of the purse for IBWC projects requiring U.S. contribution and confirmation privileges for the U.S. IBWC Commissioner. Id. at 1263-67. Although according to paragraph (h) of the Senate amendments to the treaty, the word "agreements" as used in Article 24 of the treaty proper must be interpreted to mean only those entered into as treaties between the two countries; nothing is stated explicitly about the nature of IBWC Minutes. Some U.S. officials insist that IBWC Minutes are "international agreements" not requiring ratification by the signatories. Brownell \& Eaton, supra note 63, at 270. This is not surprising; after all, to call a Minute a Treaty would ipso facto make Senate ratification necessary. The real question is whether the IBWC Minutes are mini-treaties masquerading as nebulous "agreements." 
Historically, Mexico has had little difficulty in meeting its 4(B)(c) obligation; as late as 1992, Mexico was debt-free. ${ }^{65}$ At the conclusion of the fiveyear accounting period in 1997, Mexico owed the United States just over one million acre-feet of water. ${ }^{66}$ In accordance with Article 4, Mexico's debt was added to the following accounting cycle, which closed in October of $2002 .{ }^{67}$ Currently, Mexico owes to the United States 1.37 million acre-feet of water under the provisions of subsection 4(B)(c) of the 1944 Water Treaty. ${ }^{68}$ As for the Colorado River, the United States to date has always met its annual treaty obligation to Mexico. ${ }^{69}$ Once other potential future uses are considered, such as for ecological preservation or the recognition of Native American claims, the River's resources become exhausted. ${ }^{70}$ If U.S. stakeholders press for a greater share of the river's bounty, a fresh controversy may well erupt over a United States proportional reduction in Mexican Colorado River allotments under Article 10 of the treaty.

The U.S. Supreme Court has long recognized the legal and constitutional distinction between treaties and executive agreements. That difference is explicated in the case of United States v. Belmont, 301 U.S. 324 (1937), which concerned the legitimacy of an executive agreement between the U.S. and Soviet Governments. The respondent, an American citizen, had accepted a bank deposit from a Russian corporation. Subsequently, the Soviet Government appropriated all property and assets from every Russian corporation, ostensibly including the respondent's deposit holding. In 1933, the Soviet Government assigned to the United States all claims it had to monies owed to it from American nationals, including the respondent's deposit holding. Id. at 325-26.

The Court held that the agreement was valid without the Senate's ratification. What was accomplished through the exchange of diplomatic notes was "within the competence of the President," as "the Executive had authority to speak as the sole organ of [the national] government." Id. at 330. The Court concluded that an international compact, like the one under review, "is not always a treaty which requires the participation of the Senate." Id. For a recent affirmation of the same principle, see Weinberger v. Rossi, 456 U.S. 25, 30 n.6 (1982) (recognizing that the "President may enter into certain binding agreements with foreign nations without complying with the formalities required by the Treaty Clause ....").

65. U.S. SECTION, INT'LBOUNDARY AND WATER COMM'N, UPDATE OFTHE HYDROLOGIC, Climatologic, StORaGe and RUNOFf Data roR THE UNITEd STATES IN THE MEXICAN PORTION OFTHE RIO GRANDE BASIN:OCTOBER 1992-SEPTEMBER 2002, at 2(2002) (on file with author) [hereinafter UPDATE].

66. Id. at 4.

67. Minute 308: United States Allocation of Rio Grande Waters During the last Year of the Current Cycle, June 28, 2002, U.S.-Mex., at http://www.ibwc.state.gov/html/foreign_ affairs.html (last visited Nov. 12, 2003) [hereinafter Minute 308].

68. Press Release, U.S. Section, International Boundary and Water Commission, USIBWC Announces Water Transfer (Apr. 3, 2003), at http://www.ibwc.state.gov/PAO/ CURPRESS/CurPress/watertransfer5Sbweb.htm (last visited Nov. 12, 2003) [hereinafter USIBWC Press Release].

69. But see Nitze, supra note 7, at 3 (arguing that expected population growth in the lower Colorado River Basin will make shortfalls in the Mexican allotments likely).

70. Id. 


\section{Climatological Data for the Rio Grande Basin}

The six Mexican treaty tributaries, whose Rio Grande inflows provide the source of the U.S. treaty entitlement-the Conchos, San Rodrigo, San Diego, Salado, and Escondido Rivers, and Las Vacas Arroyo-drain an area of more than 53,000 square miles, with the Rio Conchos alone draining half. ${ }^{71}$ The basin region itself is semi-arid, having an annual average rainfall of between 14 and 20 inches. $^{72}$ Although drought here is not uncommon, the typical storm can produce, even in a short period of time, tremendous runoffs, which are carried through the treaty tributaries to the Rio Grande. ${ }^{73}$

Treaty tributary inflows to the Rio Grande have varied significantly since runoffs were first measured for treaty accounting in 1953. The average yearly U.S. allotment has been 405,000 acre-feet, well above the required minimum of 350,000 acre-feet. ${ }^{74}$ Not surprisingly, tributary inflows are much smaller during years of drought: between 1993 and 1999, the average rainfall in the tributary drainage basin was 90 percent of normal ${ }^{75}$; treaty tributary inflows during the period 1994 to 1997 averaged 30 percent of the required minimum amount of 350,000 acre-feet. ${ }^{76}$ In the early 1980 s, the basin endured a drought similar in severity to that of the mid 1990s, but the inflows of the earlier period amounted to more than 70 percent of the required minimum of 350,000 acre-feet. ${ }^{77}$ In 1982, for example, rainfall was about 80 percent of normal and treaty tributary inflows amounted roughly to 75 percent of the required minimum. ${ }^{78}$ During 1997 , rainfall was in excess of 110 percent of normal, yet treaty tributary inflows amounted only to 25 percent of the required minimum. ${ }^{79}$ One is thus presented with an anomaly: the drainage basin underwent a drought during the early 1980s similar to that of the $1990 \mathrm{~s}$, but inflows during the earlier period were substantially greater than those during the similar drought years of the 1990s.

This aberration can be explained in part by Mexican water management. In the Delicias Irrigation District of the Mexican state of Chihuahua (one of the largest districts in the basin), about 28,000 acres of land were irrigated with 110,000 acre-feet of water from the Rio Conchos in $1995 .^{80}$ By 1997 ,

71. U.S. SECTION, INT'L BOUNDARY AND WATER COMM'N, UPDATE OFTHE HYDROLOGIC, Climatologic, StORage and Runoff Data For the UNITEd STATES IN THE MEXICAN PORTION OF THE RIO GRANDE BASIN: OCTOBER 1992-SEPTEMBER 2001 TECHNICAL ANNEX 1 (2002) (on file with author) [hereinafter TECHNICAL ANNEX].

72. Id.

73. Id at 2.

74. Id. at 3.

75. Id. at 7.

76. Id.

77. TECHNICAL ANNEX, supra note 71.

78. Id. at Figure 12.

79. Id.

80. Id. at Table 4. 
nearly 200,000 acres were irrigated with more than one million acre-feet of water; but in $2000,110,000$ acres were irrigated with 660,000 acre-feet. $^{81}$ Mexican water managers apparently gambled that the rains of 1996-1997 signaled the end of the drought, and therefore increased reservoir releases to Mexican farmers. ${ }^{82}$ Presumably, the subsequent reduction in irrigated acreage was because of below-normal rainfall for the years 1997 to $1999 .{ }^{83}$ Whether or not the decisions of the Mexican water managers were prudent, the conclusion that can be drawn from these data is that the drought of the last decade is not a sufficient explanation, by itself, for the size and duration of Mexico's water debt.

\section{THE POSITION OF MEXICO IN THE PRESENT CONTROVERSY}

\section{A. Mexican Water Law}

Under Paragraph 5 of Article 27 of the Mexican Constitution, all waters within the national territory are owned by the federal government. ${ }^{84}$ Therefore, as part of the national "patrimony," they are inalienable; any person or corporation seeking to exploit them for commercial use must first apply for a concession from the government. ${ }^{85}$ Through the 1992 Ley Federal de Aguas, ${ }^{86}$ the National Water Commission of Mexico $^{87}$ was granted the authority to enforce the provisions of the Water Act as the designated arm of

81. Id. These figures come close to the pre-drought average of 228,000 acres irrigated with 1.2 million acre-feet. Id.

82. Mary Kelly \& Karen Chapman, Sharing the Waters 1 (May 17, 2002), at http://www.americaspolicy.org/commentary/2002/0205water.html (last visited Nov. 12, 2003).

83. TECHNICAL ANNEX, supra note 71, at Figure 11.

84. "Son propiedad de la nación las aguas de . . los ríos y sus afluentes directos o indirectos ... [y] las corrientes constantes o intermitentes y sus afluentes directos o indirectos, cuando el cauce de aquéllas, en toda su extensión o en parte de ellas, sirva de límite al territorio nacional o a dos entidades federativas ..." MEX. CONST. art. 27 [The property of the nation includes the waters of rivers and their direct or indirect tributaries, streams that either run without interruption or are occasionally dry, and their direct or indirect tributaries, whenever the river bed serves as part or all of a territorial boundary, federal or international], available at http://www.ccdhcu.gob.mx/_leyinfo (last visited May 1, 2003).

85. "[E]l dominio de la Nación es inalienable e imprescriptible y la explotación, el uso o el aprovechamiento de [las aguas] de que se trata, por los particulares o por sociedades constituidas conforme a las leyes mexicanas, no podrá realizarse sino mediante concesiones, otorgadas por el Ejecutivo Federal, de acuerdo con las reglas y condiciones que establezcan las leyes." Id. (The ownership of the Nation is inalienable and cannot be transferred, and the exploitation, use, or availment of (the relevant waters), by persons or corporations formed in accordance with Mexican law, may not be done save through concessions, granted by the Federal Executive, in accord with the rules and conditions that the laws establish).

86. D.O., 1 de diciembre de 1992, available at http://www.ccdhcu.gob.mx/leyinfo (last visited May 1, 2003) [hereinafter Water Act].

87. Comisión Nacional de Aguas (CNA), a decentralized body of the Mexican Ministry of Agriculture and Water Resources. Id. at art. 3(V). 
the federal executive ${ }^{88}$ to serve as the arbiter for disputes among concession holders, to promote efficient water use and a culture of conservation, and to encourage scientific investigation and technical development concerning water resource management. ${ }^{89}$

Because water cannot be bought and sold like a commodity, water concessions easily lend themselves as objects of political patronage or subomation. The ruling government is given a perverse incentive to keep water rates to municipal and poor farm users artificially low so as to curry favor with voters; the upshot is a community indifferent to water waste. ${ }^{90}$ Conservation is therefore a high priority for the CNA, but it cannot afford to underwrite needed infrastructure improvements because water rates are not high enough to supply the funds, while a "culture of nonpayment" makes the issue of rate charges inconsequential. ${ }^{91}$

\section{B. Criticisms of Mexican Water Management}

In spite of Mexico's recent legislative efforts to improve its water management, ${ }^{92}$ U.S. water stakeholders continue to accuse Mexico of glaring inefficiency with some support for their charges. A recent Texas A\&M University study concludes that crops in the Mexican downstream state of Tamaulipas are growing abundantly, while Texas crops have suffered severely from insufficient irrigation. ${ }^{93}$ Most irrigation in Mexico is still done by flooding fields from earthen ditches. ${ }^{94}$ In the Delicias region of northern Mexico, an estimated 65 percent of water released to local farmers for the irrigation of crops is lost before reaching the fields. ${ }^{95}$ Mexico also has fended off allegations of water hoarding, especially directed against Chihuahua Governor Patricio Martinez. ${ }^{96}$ The atmosphere between stakeholders on both sides of the border has become acrid.

88. Id. at art. 4.

89. Id. at art. 9 (VIII, $\mathrm{XX}, \mathrm{XI}$ ).

90. Nitze, supra note 7, at 19.

91. Id. at 15. CNA experts estimate that as much as sixty percent of treaty tributary water is lost through evaporation and seepage. Id. at 14.

92. In addition to the aforementioned Water Act, supra note 86, Mexico has tried to improve its water management by seeking funds from the World Bank for hydraulic infrastructure modernization and by updating its water-rights registry, which details who is entitled to what in terms of water use. Nitze, supra note 7, at 7.

93. Kraul, supra note 4.

94. Althaus, supra note 2.

95. Id.

96. Weiner, supra note 61 . The governor has claimed that the waters of the state of Chihuahua are "sovereign"-an unorthodox Mexican constitutional interpretation. 


\section{Mexican Rejoinder}

Mexico has defended itself by claiming that the present drought has so depleted its water resources that it can barely supply the minimum needs of its own citizens, let alone meet its treaty obligations. ${ }^{97}$ Acknowledging that some of its reservoirs along treaty tributaries are far from empty, ${ }^{98}$ Mexico nevertheless asserts that, were water to be released from those same reservoirs, it would be lost through evaporation, seepage, or unlawful diversion long before it reached the Rio Grande. ${ }^{99}$ Unlike the option afforded the United States with its Colorado River obligation, ${ }^{100}$ Mexico has no similar authority under the treaty to reduce unilaterally its required inflows to the Rio Grande, even in the case of an "extraordinary drought." ${ }^{101}$ The only ambiguity Mexico can exploit is the treaty's silence as to the course to be taken when Mexico has water debts extending over two consecutive accounting cycles. But even here, the ambiguity does little to bolster the Mexican position, for at best the issue is one of how the two-cycle debt is to be paid, and not whether it can be reduced or transfers deferred. ${ }^{102}$

Some Mexican commentators have called upon their government simply to abandon the treaty and refuse to pay any water debt because the treaty itself is inequitable. ${ }^{103}$ These critics point to the inconsistency in the way the treaty

97. Two IBWC Minutes to be discussed below lend credence to the Mexican position. Minute 293: Emergency Cooperative Measures to Supply Municipal Needs of Mexican Communities Located Along the Rio Grande Downstream of Amistad Dam, Oct. 4, 1995, U.S.Mex., at http://www.ibwc.state.gov/html/ foreign_affairs.html (last visited Nov. 12, 2003) [hereinafter Minute 293], recognizing a grave imminent water shortage for Mexican borderregion municipal water users, authorized a transfer of waters belonging to the U.S. in the Rio Grande international reservoirs to Mexico to alleviate any immediate suffering. Minute 308, supra note 67, made note of the amount of water required by Mexico to meet the basic needs of its citizens for the short term and guaranteed that the United States would not call upon Mexico to make further water transfers that would decrease Mexican water levels in the international reservoirs to below that critical amount.

98. The debate over water loss through seepage or evaporation becomes moot when the water is immediately available to both countries, as it is in the case of the aforementioned reservoirs.

99. Of the largest reservoir on the Rio Conchos, La Boquilla, Mexican experts claim that any water released during the summer from the dam would be lost to evaporation or seepage before it arrived at the Rio Grande. Althaus, supra note 2. Some Texan water experts agree. Id.

100. 1944 Water Treaty, supra note 2 , at $1237-38$.

101. See id. at 1227.

102. As will be seen shortly, Minute 234: Waters of the Rio Grande Allotted to the United States from the Conchos, San Diego, San Rodrigo, Escondido and Salado Rivers and the Las Vacas Arroyo, Dec. 2, 1969, U.S.-Mex., at http://www.ibwc.state.gov/html/foreign_affairs.html (last visited Nov. 12, 2003) [hereinafter Minute 234], lays out the means by which Mexico may liquidate its Article 4(B) debt.

103. See Althaus, supra note 2 ("Newspaper columnists, especially those from the political left, have railed against the 1944 Treaty, arguing that Mexico owes nothing to its northern neighbor. Some have called on [Mexican President Vicente] Fox to renegotiate the treaty."). 
deals with debtor signatories, an example of which is found in Article 10, concerning the United States' obligation to deliver annually to Mexico 1.5 million acre-feet of water and the option given the United States in times of "extraordinary drought" to reduce its yearly obligation "in the same proportion as consumptive uses in the United States are reduced." 104 Had this provision been afforded Mexico in Article 4, there might not be today a Rio Grande water controversy, for Mexico could theoretically have claimed a reduction of its treaty obligation due to "extraordinary drought." Mexico might nevertheless argue that the present drought is so extraordinary as to go beyond that which was contemplated by the parties when the treaty was signed; or that massive agricultural and industrial development, in part spurred by NAFTA, ${ }^{105}$ has so increased the regional demand for water as to make the treaty's Rio Grande water allotments obsolete. These arguments have not yet surfaced officially in any IBWC Minute because the remedy they imply-a reallocation of Rio Grande water-is a step which arguably would move the debate beyond the IBWC Article 24 interpretation and application power into the theater of treaty renegotiation.

\section{REBUS SIC STANTIBUS}

\section{A. The doctrine defined}

Under the 1944 Water Treaty, in the case of "extraordinary drought" Mexico may add onto a second five-year cycle any and all debt accrued during the previous accounting period. ${ }^{106}$ Between 1953 and 1992, Mexico was able to meet its Article 4(B) minimum obligations, and so had no need for the drought clause. ${ }^{107}$ Because inflows assigned to the United States from the Mexican treaty tributaries averaged less than 350,000 acre-feet per year between the years 1992 and 1997, Mexico availed itself of the drought clause to add its accrued debt onto another cycle, viz. 1997 to $2002 .{ }^{108}$ As noted above, with the closing of the present accounting cycle Mexico's debt is at 1.37 million acre-feet. ${ }^{109}$ Mexico claims that its debt is due to a combination of the adverse effects of extraordinary drought and the steady increase in Mexican beneficial uses. ${ }^{110}$ Because the pertinent circumstances under which

104. 1944 Water Treaty, supra note 2 , at $1237-38$.

105. See Dellios, supra note 9.

106. 1944 Water Treaty, supra note 2 , at 1227.

107. UPDATE, supra note 65 , at 8.

108. At the conclusion of the 1992-1997 accounting cycle, Mexico owed the United States a little more than one million acre-feet. Id. at 9.

109. USIBWC Press Release, supra note 68.

110. See, e.g., Dellios, supra note 9 (quoting Mexican Agriculture Secretary Javier Usabiaga: "We have said, and we will continue to say, that with a careful administration of water, we will not have a problem making the [water] payments" (brackets in original)). Boudreaux, supra note 3 (quoting Mexican President Vicente Fox: "Today both governments 
the treaty was entered into in 1944 have changed vitally, one might argue that it would be fundamentally unfair to force Mexico to continue to observe its Article 4(B) duties; therefore, they ought to be discharged. If the dispute were to find its way before an international tribunal, Mexico could justify this position through the doctrine of rebus sic stantibus, the meaning and application of which is the subject of the following sections.

\section{Definition of rebus sic stantibus}

\section{a. The treatise writers}

Dating at least to Roman times, ${ }^{111}$ and meriting in the field of international law the grudging acceptance of no less a luminary than Grotius, ${ }^{112}$ the doctrine of rebus sic stantibus ${ }^{113}$ allows a state to excuse itself from a treaty obligation when it finds that the circumstances surrounding its accession to the treaty, upon which the provisions of the treaty were based, have so changed that the purpose of the treaty has to some degree been frustrated; in other words, a state's continued observance of the treaty's terms would produce an

and both countries understand that the problem is a lack of water, that it hasn't rained enough in 10 years and that nobody is hiding water."). See also David Rennie, Mexico and U.S. Heading for Border Water War, DAILY TELEGRAPH (London), May 31, 2002, at 19 (LEXIS Database), in reference to severe opposition to the treaty in Mexican media and political circles, quoting a Mexican official: "It has become a very emotional and political debate. [The treaty's critics] are taking advantage of this to accuse President Fox of being too close to the U.S."; Ricardo Sandoval, Officials to begin cutting off water to Valley farmers today, DALLAS MORNING NEwS, May 21, 2002, at 12A (LEXIS Database) (quoting Felipe Calderon Hinojosa, member of President Fox's PAN political party: "The drought is strong. . . We must recognize our international responsibilities and the need for water consumption by the population [in the lower Rio Grande Basin]. We must measure jointly our resources before arguing over water that does not exist, because no one can be obliged to do the impossible.").

111. See Saul Livitnoff, Force Majeure, Failure of Cause and Théorie de L'Imprévision: Louisiana Law and Beyond, 46 LA. L. REV. 1, 4 n.12 (1985) (citing Cicero and Seneca as possible originators of the doctrine).

112. The question also is commonly raised, whether promises contain in themselves the tacit condition, 'if matters remain in their present state.' To this question a negative answer must be given, unless it is perfectly clear that the present state of affairs was included in that sole reason of which we made mention. Thus constantly in the histories we read that ambassadors gave up their mission and returned home from the journey on which they had been set out, alleging as the reason that matters had been so changed that the entire matter or cause of the mission was at an end.

2 Hugo Grotius, De Jure Belli aC PaCis 424 (Francis W. Kelsey trans., Clarendon Press 1925) (1626).

113. The full doctrine is "conventio omnis intelligitur rebus sic stantibus," meaning literally "every treaty is understood by the things then standing." See 2 ROBERT PHILLIMORE, COMMENTARIES UPON INTERNATIONAL LAW 83 (Fred B. Rothman \& Co. 1985) (1855). 
inequitable result. ${ }^{114}$ The treatise writers have formulated similar definitions, ${ }^{115}$ the main difference among these being the degree to which things must change in order for the doctrine to be applied. ${ }^{116}$ Lauterpacht's exposition is the soundest, if only because it is the most conservative in delimiting the doctrine's effective scope: "[a] vital change in circumstances fundamentally affecting the intention of the treaty as it had been understood by the two parties is a valid ground for liberation from or nullification of the treaty." 117 If there be any agreement among the commentators, it is that a state ought to have some principle of international law at its disposal to allow it to avoid the especially harsh consequences that would follow from a strict adherence to a treaty's provisions, when the circumstances upon which the treaty was formed have changed to a significant degree. The challenge lies in keeping states from reducing an implied escape clause to a mere diplomatic cover for the abandonment of inconvenient promises.

\section{b. The Vienna Treaty Convention formulation}

Attempting to solve this problem, Article 62 of the Vienna Convention on the Law of Treaties, ${ }^{118}$ entitled "Fundamental change of circumstances," restricts the application of rebus sic stantibus to a change of circumstances existing "at the time of the conclusion of a treaty, which was not foreseen by the parties," if and only if (a) the changed circumstances formed the "essential basis" for the parties' consent; and (b) "the effect of the change is radically to transform" the parties' treaty obligations. ${ }^{119}$

114. But something more than mere inequity is required. See infra note 116.

115. "The principle that a treaty ceases to be binding when an essential change of the circumstances in which it was concluded has occurred." T.J. LAWRENCE, THE PRINCIPLES OF INTERNATIONAL LAW 306 (revised by Percy H. Winfield, MacMillan \& Co. 7th ed. 1930) (1895). Phillimore defines it thusly: "When that state of things which was essential to, and the moving cause of the promise or engagement, has undergone a material change, or has ceased, the foundation of the promise or engagement is gone, and their obligation has ceased." PHILLIMORE, supra note 113 , at 83.

116. Basic changes in circumstances taken for granted by the parties may permit suspension or denunciation of the treaty. GEORG SCHWARZENBERGER \& E.D. BROWN, A MANUAL OF INTERNATIONAL LAW 138 (Professional Books Ltd. 6th ed. 1976) (1947). Oppenheim would require a "vital change" in circumstances. 1 L. OPPENHEIM, INTERNATIONAL LAW: A TREATISE 550 (1905). He notes that traditionally a change in a state's form of government, e.g. from monarchy to republic or vice versa, has been considered insufficient to merit the application of the doctrine. Id. at 551. Rather, the doctrine is appropriately applied when the change in circumstances, combined with a state's continued observance of the treaty, would threaten "the existence or necessary development of a State." Id. at 550.

117. 1 HERSCH LAUTERPACHT, INTERNATIONAL LAW 421 (E. Lauterpacht ed., 1970).

118. 8 I.L.M. 679 (1969) (voted for by the United States but not ratified by the U.S. Senate) [hereinafter Vienna Treaty Convention].

119. Id. at 702. Subsection (2) of Article 62 precludes the application of rebus sic stantibus in treaties concerning boundaries, or where the change in circumstances has been caused by a party's breach. Id. Subsection (3) notes that the remedies available to a state that has successfully invoked rebus sic stantibus include termination, withdrawal, and suspension. Id. 
The first part of the Vienna formulation requires that the change in circumstances not have been foreseen by the parties. ${ }^{120}$ Therefore, merely because a change has occurred that makes a state's continued adherence to a treaty onerous is not a sufficient reason for the application of rebus sic stantibus; the change must also be one for whose effects the treaty made no provision. ${ }^{121}$ This requirement recognizes that treaties are often entered into for the purpose of insuring against untoward events; the hope is that by settling ahead of time what a state is to do in case $X$ happens, that state may be better prepared for meeting the burdens it must bear if and when $X$ comes about. ${ }^{122}$ Foreseeability is not at issue, insofar as it does not matter whether the parties to the treaty ought to have predicted a change in circumstances, but only whether in fact they did so predict. Although this distinction may be academic if one assumes that foreseeability in the abstract can be proved only by foreseeability in the concrete, nevertheless, a state seeking to invoke rebus sic stantibus under the Convention need only assert that it did not foresee the change of circumstances. ${ }^{123}$

In addition to the foreseeability requirement, a party seeking to apply rebus sic stantibus must prove that the circumstances now changed were essential to the treaty, and that the change radically altered the nature of the parties' obligations under the treaty. ${ }^{124}$ The purpose of these elements is to prevent a state from undoing the effects of what has turned out to be a bad bargain. ${ }^{125}$ Granted, a state may already have a natural incentive not to misuse the doctrine: if the state were to excuse itself from a treaty whenever it might be expedient so to do, such conduct "would certainly destroy all its credit

120. Id. art. 62(1).

121. This conclusion follows necessarily from the requirement of Article 62(1), that the changed circumstances not have been foreseen by the party invoking rebus sic stantibus; in other words, the necessary legal predicate for the application of the doctrine does not entail a review of the potential harm a party might suffer through its continued adherence to the treaty. Simply put, the change in circumstances must have been unexpected, i.e. "not foreseen."

122. The point can be explicated by analogy to the Reporter's Comment accompanying UCC § 2-615, Excuse by Failure of Presupposed Conditions. Under that section, a failure of a basic assumption of the contract does not excuse a party from the contract "when the contingency in question is sufficiently foreshadowed at the time of contracting to be included among the business risks which are fairly to be regarded as part of the dickered terms, either consciously or as a matter of reasonable, commercial interpretation from the circumstances." UNIF. COMMERCIALCODE $\$ 2-615$, 1B U.L.A. 195, 196 (1989). The circumstances surrounding a state's accession to a treaty can fittingly be understood in like manner.

123. When speaking of the parties' state of mind, Article 62 refers only to a change of circumstances "not foreseen by the parties." 8 I.L.M. at 702. The implication is that foreseeability must be actual.

124. Id.

125. Because "the goal of a treaty is always in some measure, and often to an entire measure, political, and changes in political circumstances are notoriously difficult to assess.... [rebus sic stantibus] came into marked disrepute for the obvious reason that there was no check on the occasions when it might plausibly be used." D.P. O'CONNEL, INTERNATIONAL LAW 296-97 (1965). 
among the nations." ${ }^{126}$ At the very least, one may conclude that, by its terms, Article 62 works toward making states' bad-faith use of rebus sic stantibus a more difficult business.

\section{Commentators' opinions on rebus sic stantibus}

Most of the treatise writers have shared the fear of the drafters of the Vienna Treaty Convention that states might use rebus sic stantibus in bad faith. Oppenheim acknowledges that the doctrine might easily be used in bad faith to shirk or disregard a party's treaty obligations. ${ }^{127}$ Lawrence recognizes that the real difficulty in understanding the doctrine is in how to define an "essential change," 128 a problem that the drafters of Article 62 arguably failed to address by referring merely to circumstances that are "an essential basis of the consent of the parties"129 as a necessary condition to the doctrine's application. For O'Connell, rebus sic stantibus works like an escape clause, but one which ought to be disfavored because it cannot practicably be checked; consequently, its place in international law is limited and must be taken only as a potential modifier-not terminator-of treaties. ${ }^{130}$

But simply using synonyms for substantial change, such as "essential," "vital," or "fundamental," is not helpful in understanding the operation of the doctrine in the absence of some unifying theory for governing its application. O'Connell would apply the doctrine using Anglo-American contract theory, under the headings of frustration of purpose (failure of a basic assumption) or impossibility. ${ }^{131}$ The doctrine would then apply by operation of law, a view at odds with the Vienna formulation, which takes into account the parties' intent. The two positions are not irreconcilable; ${ }^{132}$ but if, according to Lauterpacht, rebus sic stantibus is understood as a variant of frustration or impossibility, the doctrine's scope will be "severely circumscribed."133 Before reaching the theoretical undergirding of rebus sic stantibus, our discussion of the doctrine focuses first upon the relationship between the 1944 Water Treaty

126. OPPENHEIM, supra note 116 , at 551 .

127. Id. at 550.

128. LAWRENCE, supra note 115 , at 306.

129. 8 I.L.M. at 702.

130. O'CONNEL, supra note 125 , at 297 . He also claims that a treaty having an arbitration or revision clause cannot be susceptible to the doctrine's use if the latter be understood as an implied term of the treaty. Id. Article 24 of the 1944 Water Treaty makes the IBWC the principal arbitrator of disputes arising under the treaty. 1944 Water Treaty, supra note 2, at 1256. Whether this fact would preclude Mexico's use of the doctrine will be discussed in the following section on frustration of purpose. See infra Part IV.B.3. This view is a variant of the doctrine of casus foederis, literally meaning "the case of the treaty"; it holds that a treaty cannot be avoided when the complained of events were made part of the treaty's provisions.

131. O'CONNEL, supra note 125, at 298 (following Fitzmaurice, id.).

132. Changed circumstances that frustrate or make impossible the performance of a treaty may be probative of the parties' actual intent at the time of the treaty's creation.

133. LAUTERPACHT, supra note 117 , at 422. 
and the U.S. Supreme Court, any role the latter might have in the interpretation of the former, the latter's interpretation of treaties generally, and, in particular, the latter's position vis à vis rebus sic stantibus.

\section{The U.S. Supreme Court and treaties}

The U.S. Constitution extends the judicial power of the United States to cases "arising under this Constitution, the Laws of the United States, and Treaties made, or shall be made, under their Authority." 34 The Supreme Court therefore has the authority to hear disputes arising under the treaties to which the United States is a party. ${ }^{135}$ It does not necessarily follow, however, that the Court has the power to hear disputes arising under the 1944 Water Treaty. The appellate procedure adopted by Article 24(d) is two-fold: the Commissioners of the IBWC are to try to reach an agreement, and if they fail, the dispute is to be referred to the two governments "for discussion and adjustment of the difference through diplomatic channels and for application where proper of the general or specific agreements which the two Governments have concluded for the settlement of controversies." ${ }^{136}$ At first blush the 1944 Water Treaty leaves no room for intervention on the part of the U.S. Supreme Court.

Nevertheless, a case can be laid out wherein the Court's intervention might be sought and be legally binding upon the Executive Branch. Assuming arguendo that the United States and Mexico were to agree to an application of rebus sic stantibus that reduces or eliminates Mexico's Article 4(B) debt, such an agreement could undoubtedly be taken for a modification of the parties' existing rights and therefore tantamount to a treaty amendment requiring the U.S. Senate's "Advice and Consent."137 But who could challenge the Executive Branch's interpretation of the agreement?

\section{U.S. CONST. art. III, $§ 2$.}

135. But it is one thing for the Court to hear disputes arising under a treaty and another to approve of or circumscribe the actions concerning a treaty of a coordinate branch of the federal government. This latter version of judicial review of treaties has traditionally been considered under the heading of political question. See, e.g., Goldwater v. Carter, 444 U.S. 996, 998 (1979) (Powell, J., concurring) (setting forth a three-part analysis: one, whether the text of the Constitution commits the question to a political branch of government; two, whether the question requires for its resolution expertise that the Court does not have; and three, whether prudential considerations weigh against the Court hearing the question); in the context of property rights, see U.S. v. Sandoval, 167 U.S. 278, 290 (1897) ("The mode in which private rights of property may be secured, and the obligations imposed upon the United States by treaties fulfilled, [belong] to the political department of the government to provide.").

136. 1944 Water Treaty, supra note 2, at 1256.

137. See U.S. CoNST. art. II, \& 2, cl. 2. See also UNITED STATES AND MEXICo ColORADO RIVER DELTA SYMPOSIUM 23-24 (Sept. 11-12, 2001), at http://www.ibwc.state.gov/FAO/ CRDS0901/EnglishSymposium.pdf (last visited Nov. 12, 2003) [hereinafter SYMPOSIUM]: "[A]ny amendment of the treaty, i.e. a modification of existing rights and obligations, would require that agreement be submitted to the United States Senate for its advice and consent." (reduction of the statement of U.S. Department of State symposium representative Mary Brandt). 


\section{a. A question of standing}

As a preliminary matter, not all international agreements are treaties as understood by Article II of the Constitution. Although it is well settled that the Executive Branch's authority under the Constitution to conduct the nation's foreign policy includes the power to make various kinds of bilateral and multilateral accords, agreements, and understandings, without compliance with the Treaty Clause, ${ }^{138}$ the line between an international agreement and a treaty, for constitutional purposes, is a blurry one. In dealing with the 1944 Water Treaty, an IBWC Minute that pretended to change Mexico's existing Article 4(B) debt might fairly be interpreted as a substantial change in the parties' rights and obligations theretofore assumed. ${ }^{139}$

The argument can be made that such an agreement would be a de facto treaty amendment, therefore triggering the requirements of the Treaty Clause; but, it is an entirely separate and much more difficult question as to who would have standing to challenge the Executive Branch's claim that the agreement falls within that Branch's foreign policy prerogative. This issue is resolved through recourse to the Supreme Court's standing jurisprudence, which is divided into two categories: the constitutional and the prudential. In the former category, the threshold question is whether the plaintiff presents a case within the meaning of Article III, section 2 of the Constitution. That query is answered by determining (1) whether the plaintiff has a sufficient stake in the matter to justify federal jurisdiction and the Court's remedial powers, and (2) whether the plaintiff has suffered or will suffer some injury because of the impugned action. ${ }^{140}$

If the plaintiff passes the constitutional test, standing then turns upon the Court's prudential judgment. A plaintiff will fail this prudential test if (1) his alleged injury is a "generalized grievance" shared by a large class of

138. See 1944 Water Treaty, supra note 64.

139. "[A] treaty is amended only if the obligations imposed by that treaty change." New York Chinese Television Programs, Inc. v. U.E. Enterprises, 954 F.2d 847, 854 (2d Cir. 1992). In deciding whether the United States's "derecognition" of Taiwan affected the reciprocal copyright protection agreements in force between the two countries, the court agreed with the "defendants' assertion that a significant amendment to a treaty must follow the mandate of the Treaty Clause, and therefore must be proposed by the President, and be ratified following the advice and consent of the Senate." Id. at 853.

140. Warth v. Seldin, 422 U.S. $490,498-99$ (1975). There is a long line of case law supporting the proposition that the plaintiff, in order to have standing, must assert some constitutional right personal to himself, or at least personal to someone so closely connected to the plaintiff as to make the two parties practically indistinguishable. See McGowan v. Maryland, 366 U.S. 420, 429 (1961); United States v. Raines, 362 U.S. 17, 20-22 (1960); NAACP v. Alabama ex rel. Patterson, 357 U.S. 449, 459 (1958); Voeller v. Neilston Warehouse Co., 311 U.S. 531, 537 (1941); Hendrick v. Maryland, 235 U.S. 610, 621 (1915); Tyler v. Judges of Court of Registration, 179 U.S. 405, 408-10 (1900). 
citizens, ${ }^{141}(2)$ he asserts rights not personal to himself,${ }^{142}$ or (3) the Constitutional provision at issue cannot be read either explicitly or implicitly to grant persons in the plaintiff's position a right to relief. ${ }^{143}$ As an exception to the requirement that the plaintiff assert rights personal to himself, the Court will permit a plaintiff to assert the rights of third parties if the interests involved are grave enough, they would be violated by the impugned action, and the connection between the plaintiff and the third parties is more than a mere "incidental congruity of interest."

\section{b. Standing and the Treaty Clause}

Applying this standing test to the hypothetical agreement aforementioned, it is possible that a number of persons or entities would have standing to contest the Executive Branch's interpretation. To begin with, thirty-four Senators, representing one-third plus one of the Senate, who would vote against the agreement were it to be presented, could assert that their Treaty Clause voting rights were violated by the Executive Branch's failure to present the agreement to the Senate. ${ }^{145}$ The Senators' constitutional stake would be substantial; their injury-inability to vote-would be a direct result of the Executive Branch's action; the injury would not be a "generalized grievance"; and the rights asserted would be personal to the Senators. In sum, they would likely have standing to contest the agreement.

It is less clear whether standing would exist for a state, such as Texas, or for individual citizens, to contest the Executive Branch's failure to present the impugned agreement to the Senate for ratification. For these parties, the central question would be whether their injuries, presumably caused by the diminution in water that was to be supplied by Mexico, could be linked to the deprivation of the Senators' voting rights, which would be the primary injury stemming from the violation of the Treaty Clause. The Court has held that the injury complained of can be indirectly related to the Constitutional violation, but in all cases it must be "fairly traceable to the defendant's acts or omissions." 146 The issue would be decided upon whether the state's or the citizen's interests were related to those of the Senators in such a way as to be more than

141. Warth, 422 U.S. at 499.

142. Id.

143. Id. at 500.

144. Id. at 510.

145. This situation is distinguishable from the facts of Goldwater v. Carter, 444 U.S. 996 (1979), discussed supra note 135; whereas in Goldwater the matter in dispute was the constitutional role the Congress was required to play in a President's abrogation of a treaty, in a hypothetical Rio Grande dispute the issue would be whether the Executive Branch had agreed to a de facto amendment to the 1944 Water Treaty, which would require Senate ratification. See New York Chinese Television Programs, 954 F.2d at 853.

146. Vill. of Arlington Heights v. Metro. Hous. Dev. Corp., 429 U.S. 252, 261 (1977). 
mere "incidental congruity of interest." 147 Given the gravity of a Treaty Clause violation, the Court would be most reluctant to extend standing to third parties if the persons whose injury would be direct and primary, i.e. the 34 Senators in the present example, had not sought redress of their own accord. ${ }^{148}$ But even if this be so, it is at least theoretically possible that the Court could be called upon to adjudicate a matter arising under the 1944 Water Treaty, despite the absence of any explicit provision in the latter for judicial review. ${ }^{149}$

\section{c. The U.S. Supreme Court's general rules for treaty interpretation}

The modern rule followed by the Court in treaty interpretation has been to take the treaty as a contract between the parties, subject to the normal modes of contract interpretation. ${ }^{150}$ Chan $v$. Korean Airlines, Ltd. ${ }^{151}$ presented the question of whether the Warsaw Convention precluded a limit on liability where adequate notice of the limit was not given. The Court held, in an opinion by Justice Scalia, that where the text of the treaty is clear, the Court has no power to insert an amendment ${ }^{152}$ :

147. Warth, 422 U.S. at 510.

148. See id. at 499.

149. This standing discussion does not exhaust the ways in which the decisions of the Supreme Court could play a role in the adjudication by an international tribunal of the present Rio Grande controversy. Because the Court's decisions regarding the uses of streams running through the several states are analogous to those rendered by an international tribunal judging the rights of sovereign nations, they form authoritative precedent in international law. The Court's opinions in interstate water disputes were so used by the Trail Smelter Arbitral Tribunal, which settled the case of the Trail Smelter, a controversy between the U.S. and Canada over the latter's operation of an iron smelter near the British Columbia-Washington State border. Trail Smelter Arbitral Tribunal Decision, reprinted in 35 AMER. J. INT'L L. 684(1941). The smelter, between the years 1925 and 1937, caused severe damage to Washington State through its sulphur dioxide emissions. Id. at 692-93. In ruling in favor of the U.S., the tribunal stated that

as regards, both air pollution and water pollution, certain decisions of the Supreme Court of the United States ... may legitimately be taken as a guide in this field of international law, for it is reasonable to follow by analogy, in international cases, precedents established by that court in dealing with controversies between States of the Union or with other controversies concerning the quasi-sovereign rights of such states, where no contrary rule prevails in international law and no reason for rejecting such precedents can be adduced from the limitations of sovereignty inherent in the Constitution of the United States.

Id. at 714 .

150. For the earlier view, see Haver v. Yaker, 76 U.S. 32, 35 (1869): "In this country, a treaty is something more than a contract, for the Federal Constitution declares it to be the law of the land" (deciding whether the relate-back theory for determining the effective date of treaties would apply when its operation would divest a private citizen of a property interest). See also Choctaw Nation v. U.S., 318 U.S. 423, 431 (1943) ("[T]reaties are construed more liberally than private agreements.").

151. 490 U.S. 122 (1989).

152. Id. at 134 . The drafting history of the treaty, known as travaux préparatoires, may be consulted only when the text is ambiguous. Id. 
Neither can this Court supply a casus omissus in a treaty, any more than in a law. We are to find out the intention of the parties by the just rules of interpretation applied to the subject matter; and having found that, our duty is to follow it as far as it goes, and to stop where that stops-whatever may be the imperfections or difficulties which it leaves behind. ${ }^{153}$

Simply put, "[a] treaty is in the nature of a contract,"154 made between nations to which "general rules of construction apply."155 The words of a treaty are to be taken according to their ordinary meaning in international law. ${ }^{156}$ Moreover, in interpreting international agreements and treaties, one must allow for a heavy presumption in favor of the literal meaning of the words used therein. ${ }^{157}$ Accordingly, the following may be taken as the general rules of construction adhered to by the Supreme Court in the interpretation of treaties: (1) the plain meaning of the words is controlling; (2) travaux préparatoires may be referred to only where the text is ambiguous; and (3) treaties as a whole are interpreted as contracts between states.

\section{The U.S. Supreme Court's interpretation of rebus sic stantibus}

Research has turned up but one case in which the Supreme Court has directly addressed the doctrine of rebus sic stantibus, viz. Trans World Airlines, Ltd. v. Franklin Mint Corp. In Franklin Mint, the respondent had lost cargo which it had shipped with the petitioner TWA, and sought damages according to the Warsaw Convention. ${ }^{158}$ Under the Convention, the calculation of damages is tied to a state's gold standard, which in the United States was last at $\$ 9.07$ per troy ounce before Congress eliminated it in 1978..$^{159}$ The respondent had shipped coins valued at over $\$ 250,000$, but under the treaty's gold standard provisions, the damages would have amounted to about $\$ 6,000$, based upon the weight of the coins. ${ }^{160}$ Franklin Mint argued that a treaty ceases to be binding when there has been a substantial change since its promulgation, ${ }^{161}$ a position tantamount to rebus sic stantibus. The Court noted that the "doctrine of rebus sic stantibus does recognize that a nation that is party to a treaty might conceivably invoke changed circumstances as an excuse for terminating its

153. Id. at 135 (quoting The Amiable Isabella, 6 Wheat. 1, 71 (1821)) (Story, J.).

154. Trans World Airlines, Inc. v. Franklin Mint Corp., 466 U.S. 243, 253 (1984).

155. Id. at 262 (Stevens, J., dissenting).

156. Id. at 263.

157. Id. at 262.

158. Trans World Airlines, 466 U.S. at 245 (majority opinion).

159. Id.

160. Id. at 246.

161. Id. at 253. 
obligations under the treaty."162 Nevertheless, Franklin Mint lost; the Court found that a private party could not invoke the doctrine on behalf of a treaty signatory merely because the private party finds "the continued existence of the treaty inconvenient."163 Franklin Mint confirms that the Supreme Court recognizes rebus sic stantibus as a part of international law.

The Court's opinion does not reach the question of how and when the doctrine ought to be applied by states, although from the case's result it is clear that merely an inequitable result (which surely is the case when Franklin Mint's damages represent less than three percent of its actual loss) is not a sufficient basis for the doctrine's application. This result underscores the Court's reluctance to disturb the contractual balance struck by a treaty, even where that balance has proved to be a bad bargain in light of a change in circumstances. In its effort to limit in theory the scope of the doctrine's application, the Court is in accord both with the treatise writers and the Vienna drafters.

The search for a unifying theory for the application of rebus sic stantibus to the controversy over Mexico's Article 4(B) debt leads now to a review of the contract doctrines of impracticability, impossibility, and frustration of purpose. Their exposition and application to Mexico's water debt under the 1944 Water Treaty is the subject of the following section.

\section{B. Rebus sic stantibus and contract theory}

The relevance of this investigation into contract theory is based upon three premises, two of which have already been dealt with, viz. a treaty is interpreted as a contract among states, and rebus sic stantibus is susceptible to a contract-theory interpretation. ${ }^{164}$ The third premise is this: the plain language ${ }^{165}$ of the treaty permits Mexico what amounts to a delay in debt payment in the case of an "extraordinary drought," but no other remedy. Therefore, to justify noncompliance Mexico must allege either (a) the combination of drought and increased beneficial uses has made Mexico's continued adherence to the treaty either impracticable or impossible, thereby representing a change in circumstances sufficient to merit the application of

162. Id.

163. Id.

164. See, e.g., John D. Calamari \& JosePh M. PERILLo, TheLAW ofConTRACTS 530 (4th ed. 1998) (wherein it is stated that an unexpected event making a substantial change in contemplated performance is tantamount to rebus sic stantibus, "an implied term in every treaty [operating such that the treaty] will cease to be binding when the facts and conditions on which it was based have fundamentally changed.").

165. Bearing in mind that " $[t]$ raditionally, courts will give the language [of the contract] its natural and appropriate meaning, and if the words are unambiguous, will not admit evidence of what the parties may have thought the meaning to be," an exposition of the plain-meaning rule. 1 SAMUEL WILLISTON \& RICHARD A. LORD, A TREATISE ON THE LAW OF CONTRACTS $§$ $6.58(1991)$. 
rebus sic stantibus; or (b)(i) because of drought and increased uses the debt Mexico has incurred amounts to a frustration of the purpose of the treaty, viz. the equitable division of the waters of the three international streams ${ }^{166}$; or, in the alternative, (ii) the failure of a basic assumption of the treaty, the assumption being that the enforcement of the treaty as contemplated by the parties at its creation would not itself produce an inequitable result.

\section{Rebus sic stantibus understood through Impracticability ${ }^{167}$}

The Restatement (Second) of Contracts permits the discharge of a party's duty to perform, in the absence of contrary language, when that "party's performance is made impracticable without his fault by the occurrence of an event the non-occurrence of which was a basic assumption on which the contract was made ...."168 Even assuming that a "basic assumption" is the equivalent of "changed circumstances" within the meaning of rebus sic stantibus, one will still find the definition ill-suited for practicable application, as the Restatement definition merely states that one has a good impracticability defense when it would be impracticable to perform-and that is question begging. A similar definition is found in UCC $\S 2-615$, wherein the discharge of a party's duty is predicated upon the failure of a basic assumption rendering performance impracticable. ${ }^{169}$ The Reporter's Comment notes that increased cost alone is insufficient reason for discharge, but "[i]n the case of a failure of a production by an agreed source for causes beyond the seller's control, the seller should ... be excused since production by an agreed source is without more a basic assumption of the contract." 170 It is here that Mexico has by analogy a good argument, one which can be made out in the following manner: if Mexico be considered the seller, the thing sold be water, the agreed source be the heavens, and a failure of production be drought, then the present Rio Grande controversy would meet all of the elements of an impracticability defense, for whence is the water to come save from above?

This analogy becomes untenable, however, when impracticability is predicated upon a meteorological phenomenon: "The fact that storms, or unusual weather conditions make performance more difficult or expensive has generally been held to be no excuse." ${ }^{171}$ Because rain, like weather in general, is difficult to predict, it makes sense that parties would seek to allocate the risk of drought between themselves; and even if one cannot make it rain, one can still insure the other party for losses resulting from a lack of rain. The purpose

166. See 1944 Water Treaty, supra note 2 , at 1220.

167. Although the doctrine of impracticability has traditionally been considered a subdoctrine of impossibility, for present purposes the two will be treated separately.

168. RESTATEMENT (SECOND) OF CONTRACTS $§ 261$ (1979).

169. UNIF. COMMERCIAL CODE $§ 2-615$, 1B U.L.A. 195 (1989).

170. Id. at 196.

171. 6 ARTHUR LINTON CORBIN, CORBIN ON CONTRACTS $\S 1333$ (1962). 
of the Article 4(B) requirements was to secure a minimal water supply for Texas irrigators. This guarantee was thought necessary because, south of Fort Quitman, Texas, seventy percent of the flow of the Rio Grande comes from Mexican tributaries. The "extraordinary drought" language of the treaty might thus be understood as an allocation to Mexico of the risks of drought.

But impracticability requires more than the failure of a basic assumption (or changed circumstances); the failure must not have been reasonably foreseeable at the time of contracting. ${ }^{172}$ A state may claim rebus sic stantibus as a way of avoiding onerous treaty provisions if the state is believed when it claims that it did not foresee at the time the treaty went into force that circumstances might change down the road, whereas a contractual party seeking to excuse himself through impracticability must do more, viz. prove that the events causing the impracticability were not reasonably foreseeable. ${ }^{173}$ According to the relevant climatological data, droughts of varying magnitude and severity had occurred prior to the treaty's ratification, and have recurred with some frequency in the sixty years since. ${ }^{174}$ In other words, it would be difficult for Mexico to prove that it did not foresee, or ought not to have foreseen, that drought might make its Rio Grande allotment obligations hard to meet. Therefore, Mexican noncompliance with its Article 4(B) obligations, based upon a theory of rebus sic stantibus understood through impracticability, cannot be justified.

\section{Rebus sic stantibus understood through Impossibility}

Impossibility is closely related to impracticability, the only difference between the two theories being that, in the case of the latter, performance would be possible but exceptionally burdensome, whereas in the case of the former, performance cannot even be compelled, usually because the thing serving as the basis of the contract has ceased to exist. Taylor v. Caldwell ${ }^{175}$

172. Contrariwise, the Vienna Treaty Convention formulation of rebus sic stantibus requires actual, not reasonable or imputed, foreseeability. See supra Part IV.A.1.b. and note 123.

173. The exemplar for this view is Eastern Airlines v. GulfOil, 415 F. Supp. 429 (S.D. Fla. 1975). The court, rejecting the defendant's UCC impracticability defense to an output requirements contract, concluded: "Gulf would not prevail because the events associated with the so-called energy crisis were reasonably foreseeable at the time the contract was executed." Id. at 441 (emphasis added).

174. In discussing the urgent need for a water treaty for the Rio Grande, L.M. Lawson, American Commissioner of the IBC, referred "to a very serious situation; one, of last summer, where a drought condition prevailed for some weeks, threatening investment and involving even community life through the domestic water supply." Hearings, supra note 15, at 25 . Lawson also noted that, immediately prior to the flood year of 1932 , there was a "drought period which was so serious that drinking water was shipped in Brownsville, Tex., by carload." Id. at 26. See also supra Part II.C.

175. 122 Eng. Rep. 309 (K.B. 1863). The plaintiff was a symphony orchestra that had contracted to rent from the defendant a concert hall. The plaintiff had, in reliance upon the contract, made several expenses in preparation for the concert. The hall burned down before 
is the paragon case for impossibility. Its definition of the doctrine has become standard: "in contracts in which the performance depends on the continued existence of a given person or thing, a condition is implied that the impossibility of performance arising from the perishing of the person or thing shall excuse the performance." 176 The analogy to the present Rio Grande controversy may be drawn thusly: the performance of Mexico (transferring of water) depends upon the continued existence of a thing (water), which has perished (because of drought), rendering performance impossible. To be sure, Mexico can comply with the treaty, but compliance entails the risk of severe water shortages that could affect municipal supplies. The product of the analogy, then, is a form of practical impossibility.

This ungainly result need not discourage further inquiry, for the Vienna Treaty Convention also makes allowance, in Article 61, for "Supervening impossibility of performance." 177 So long as the impossibility stems from the "disappearance or destruction of an object indispensable for the execution of the treaty," the party is excused from performing. ${ }^{178}$ Although the Vienna codification of impossibility cannot be said to be superior in clarity or simplicity to that found in Taylor, it does carry with it the weight of international law, and therefore makes a more convincing argument for Mexico than does impracticability.

Nevertheless, the 1944 Water Treaty and the impossibility doctrine make an ill fit. In the treaty, the parties did not contract for the delivery of a certain quantity of water, or for water as a thing, but rather for a supply of the thing. It is true that without water the treaty cannot operate, but the water contracted for has neither "disappeared" nor has it been "destroyed"-it simply has not fallen from the sky. In other words, the debt that Mexico has accrued under Article 4(B) represents water that has never existed; it does not stand for water that has once been but now no longer is. Therefore, because here there has been no "perishing" of the thing contracted for, the impossibility defense, under either the Taylor or the Vienna formulation, fails.

\section{Rebus sic stantibus understood through Frustration (failure of a basic assumption)}

The doctrine of failure of a basic assumption has already been treated in part under the headings of impracticability and impossibility, at least insofar as these latter theories require such a failure as a precondition to the working of their defenses. The doctrine of frustration in this respect is differ-

the concert could take place, and the plaintiff sued for damages based upon breach of the contract, which itself was silent as to what ought to be done if the hall were to become unavailable.

176. Id. at 314 (opinion by Blackburn, J.).

177. 8 I.L.M. 679, 702 (1969).

178. Id. 
ent: when it has served to discharge a party from its contractual obligations, the performance avoided was neither impracticable nor impossible. This is so because frustration is concerned not with the mechanics of performance but with the reason for performance; it operates where there has been a failure of consideration. ${ }^{179}$ The English version of the doctrine can be found in Lord Justice Vaughan Williams's opinion in Krell v. Henry ${ }^{180}$ in the form of a threepart test: (1) what was the foundation of the contract? If that foundation was the impeding (frustrating) event, then (2) was the performance of the contract prevented? If so, then (3) was the impeding event such that neither party could have contemplated its occurrence at the time of contracting? If yes, then the duty is discharged. ${ }^{181}$

In this country, the doctrine has received its most lucid exposition in the opinion of Justice Traynor in Lloyd v. Murphy. ${ }^{182}$ Traynor described frustration as when "[p]erformance remains possible but the expected value of performance to the party seeking to be excused has been destroyed by a fortuitous event, which supervenes to cause an actual but not literal failure of consideration." 183 This formulation differs only slightly from that of Vaughn Williams's in Krell, but Traynor distinguishes himself in admitting that the "question in cases involving frustration is whether the equities of the case, considered in light of sound public policy, require placing the risk of a disruption or complete destruction of the contract equilibrium on defendant or plaintiff ...."184

The purpose of the 1944 Water Treaty is "to obtain the most complete and satisfactory utilization" of three international streams. ${ }^{185}$ The purpose of Article $4(B)$ is to assure Texas irrigators a minimum supply of water. ${ }^{186}$

179. Courts try to identify both parties' intentions, and "when the presuppositions or assumptions of one or both parties are disrupted or frustrated in a fundamental way some remedial action may be justified." 14 ARTHUR LINTON CORBIN, CORBIN ON CONTRACTS $\$ 77.1$ (Joseph M. Perillo ed., 2001). Typically a party can still perform but the reason for performance no longer exists. Id. at 243.

180. One of the famed "Coronation Cases." L.R. 2 K.B. 740 (Ct. App. 1903).

181. Id. at 751. When element two speaks of the performance being prevented, one must assume the Lord Justice meant that the impeding event renders the contract valueless to one of the parties; if not, then the test more aptly describes impossibility.

182. 153 P.2d 47 (Cal. 1944). The case involved a lessee who had sought a lot on which to conduct a new automobile sales business. After the lease was executed, the U.S. Government issued a war-time regulation severely restricting the market for new automobiles; consequently, the value of the lease was allegedly substantially reduced and the lessee sought discharge.

183. Id. at 50 .

184. Id.

185. 1944 Water Treaty, supra note 2 , at 1220.

186. See, e.g., the statement of Secretary of State Edward Stettinius before the Senate Foreign Relations Committee during the hearings for the treaty's ratification: "On the lower Rio Grande, where most of the water supply originates in Mexico, a division of the waters was agreed upon which ... will protect existing uses and make possible considerable expansion in both countries." Hearings, supra note 15, at 20. As for the American motive in demanding a baseline water guarantee, see the exchange between Senator Downey of California and L.M. Lawson, Commissioner of the IBC: 
Would those purposes be frustrated if Mexico were to be excused from its 4(B) obligations; or, in the words of Traynor, would the contract equilibrium made by the treaty be upset? It is here that Mexico can make a good argument, in that the provisions as now enforced have proved to be a burden far beyond any Mexico has borne since the treaty's creation. Even if the drought now besetting the region be not considered beyond the pale of extraordinary, the tremendous increase in beneficial uses on both sides of the border, coupled with water waste, have turned the treaty into a worker of inequity. The value to Mexico of a perpetual treaty purporting to divide fairly the waters of shared streams is nil when the treaty proves to be an unequal allocator. If this substantial unfairness is deemed to frustrate the purpose of the treaty, and if the drought, waste, and increased demand found on both sides of the Rio Grande are deemed a significant change in circumstances, then this may be an apt spot for the application of rebus sic stantibus.

\section{THE POSITION OF THE UNITED STATES IN THE PRESENT CONTROVERSY}

The approach of the United States to the current water dispute has been a simple one: tactfully but insistently to demand Mexican compliance with the terms of the treaty. ${ }^{187}$ The United States has no interest in renegotiating a treaty favorable to it, but even if certain incentives existed for renegotiation, the potential political upheaval that would result from upset and betrayed farmers in vote-rich Texas would exceed any benefit to be gained in AngloMexican relations. ${ }^{188}$ In any event, the United States points to precedent in resolving the conflict: IBWC Minute 234. This pronouncement of the Commission, made in the wake of Mexico's construction of the Luis Leon Dam along the Rio Conchos, ${ }^{189}$ lays out the means by which Mexico is to pay any water debt accruing under Article 4 of the 1944 Water Treaty. ${ }^{190}$ Deficiencies may be made up by (a) any water allotted to the United States from the named

Senator Downey. Would you then term that [article 4(B)] a very favorable arrangement to the State of Texas and to the users of the Rio Grande?

Mr. Lawson. Absolutely. It is to their benefit. Mexico is in a position by these [dams] on the [treaty] tributaries to control practically the entire flow.

Id. at 30. Since the signing of the treaty, Mexico has built six reservoirs of varying capacity along treaty tributaries, bringing the total number of Mexican dams in the basin to twelve. TECHNICAL ANNEX, supra note 71, at Table 1.

187. "It's our position that with the current water storage, projected inflows and reduced irrigation, Mexico could make deliveries in partial fulfillment of its obligations." (statement of Sally Spener, spokeswoman for the USIBWC), Chris Kraul, Doubts Sprout About Mexico Water Pledges, L.A. TIMES, May 29, 2002, at A3.

188. "We feel abandoned by a home-grown president who knew what was happening all along." (statement of Jo Jo White, manager of one of Texas's largest border region irrigation districts), Weiner, supra note 61.

189. UPDATE, supra note 65 , at 3.

190. Minute 234, supra note 102. 
tributaries in excess of the United States guaranteed minimum allotment ${ }^{191}$; (b) any water allotted to Mexico from the named tributaries, when Mexico gives the United States notice and the United States is able to store such waters; and (c) any water allotted to Mexico that is stored in one of the major international dams along the Rio Grande, to the extent that the United States is able to conserve such waters. ${ }^{192}$ Accordingly, the current water dispute, in the eyes of the United States, is simply a matter of inducing Mexico's compliance with these existing provisions.

So as not to appear hard-nosed over the treaty, the United States has sought repeatedly through the IBWC to alleviate any genuine hardship befallen upon Mexico because of drought. One example of this attitude can be found in Minute $240,{ }^{193}$ which was issued in response to a drought in the Baja California region of Mexico that threatened the municipal water supply of Tijuana. ${ }^{194}$ Point 1 of the Minute mandated that, for a limited period of time, deliveries of Mexican water allotted under Article 10(a) of the 1944 Water Treaty would be made at a point along the border near Tijuana. ${ }^{195}$ These deliveries were significant because they broke with the pre-existing framework for Colorado River allotment transfers to Mexico, but this alteration in practice and established procedure did not preclude the two countries and the IBWC from working out a solution to an emergency situation within the confines of the 1944 Water Treaty.

IBWC Minute 293, issued in 1995, is another good example both of U.S. conciliation and of the IBWC taking significant liberties with the interpretive power granted to it by the treaty. The Minute noted the existence of a drought-induced "critical situation" in the Rio Grande Basin which threatened the water supply for domestic use by Mexican citizens living near the river. ${ }^{196}$ The IBWC Commissioners also recognized the conservation measures undertaken by Mexico, including "elimination of irrigation releases, utilization of farm labor [to repair infrastructure], drilling of wells . . . and maintenance of a reserve of . . 121,606 acre-feet (af) at the international dams for domestic and municipal supply," but conceded that such measures

191. No better example of "robbing Peter to pay Paul" can be found. The provision's use of "minimum" must be taken for the 350,000 acre-feet per year average. If the Commissioners meant by "minimum" the standard one-third allotment (which may be greater than the 350,000 figure), anything in excess of that amount perforce is Mexican water, as covered by subparagraph (b) of the same Minute. Therefore, the U.S. takes as a Mexican payment water in excess of its guaranteed minimum but water which would normally be allotted to it anyway. That Mexico has not pressed its case under this provision can be explained only by the vagaries of diplomacy and not by any slavish adherence to self-interest.

192. Minute 234, supra note 102 , at 2.

193. Colorado River Waters: Emergency Deliveries to Tijuana, June 13, 1972, U.S.-Mex., 28 U.S.T. 7169.

194. Id. at 7170 .

195. Id. at 7172-73.

196. Minute 293, supra note 97 , at 1 . 
were insufficient to guarantee a minimum supply of water for essential Mexican uses. ${ }^{197}$ The treaty provides in Article 9(f) that when there is "extraordinary drought in one country with an abundant supply of water in the other country, water stored in the international storage reservoirs and belonging to the country enjoying such abundant water supply may be withdrawn, with the consent of the Commission, for the use of the country undergoing the drought." 198 The Commissioners, aware that U.S. water levels were below normal in both international reservoirs, nevertheless decided "in the spirit of Article 9 of the 1944 Water Treaty" to consider measures to alleviate Mexico's severe shortage. ${ }^{199}$ In spite of the evident international goodwill exuded by both parties, the United States was quick to "reinforce, at the earliest time possible, the Commission's procedures set forth in the 1944 Water Treaty governing ... the measurement, conveyance, storage and diversion of waters belonging to each country." allowing Mexico to divert for domestic and municipal needs waters from the Rio Conchos reaching the main channel of the Rio Grande normally allotted to the United States, up to 81,071 acre-feet. ${ }^{201}$

Two points can be made about Minute 293 that are relevant to the current water dispute. First, the U.S. concession reveals an important American bargaining position, viz. that the United States will press for Mexican action in accord with Article 4 so long as Mexico retains sufficient water to ensure that domestic and municipal uses can be taken care of. If any further payment by Mexico of its water debt would result in a cutting into of what can be called Mexico's "critical supply" of water, the United States is quick to back away and adopt a more accommodating and publicly conciliatory attitude. Such a method of attack serves several purposes: it satisfies Texas stakeholders as they watch their crops wilt under the ravages of drought; it keeps Mexican critics at bay by blunting the effect of otherwise "inequitable" results under the treaty; and it reinforces the U.S. adherence to Article 3 of the treaty and its preferential guide to beneficial water uses. As far as this last motive goes, it would make little sense for the United States to allow Mexico temporary use of American water destined for irrigation of Mexican crops,

197. Id. at 1-2. Although touted only as a guide, the preferential listing of allowed uses under Article 3 of the treaty carries significant weight. Number one is "Domestic and municipal uses." 1944 Water Treaty, supra note 2, at 1225.

198. 1944 Water Treaty, supra note 2, at 1235.

199. Minute 293, supra note 97, at 2.

200. Id. at 3.

201. Id. at 4. Note that the waters transferred are those of the Rio Conchos reaching the Rio Grande; until that point, the U.S. has no claim under the treaty to those waters. Of course, if Mexico wishes to supply its citizens with water from the international storage dams, it has no choice but to transfer the waters by way of the Rio Grande. Once the tributary waters enter the main channel, the allotment provisions of Article 4 apply. Point 4 of the same Minute emphasizes that the emergency release of water "does not in any way represent a waiver of the rights established for the United States in Article 4 of the Water Treaty of 1944." Id. 
given that these same Mexican farmers have as their chief competitor Texas farmers and have as their chief market American grocery stores. ${ }^{202}$

Second, the Minute demonstrates the IBWC's willingness to interpret in a very loose manner the provisions of the treaty in order to achieve a result amenable to both sides. To use the word "abundant" to describe the U.S. supply of water in the Rio Grande international reservoirs, either in 1995 or now, ventures a solecism, but that did not stop the IBWC Commissioners from divining a treaty spirit friendly to Mexican and American interests. The lesson to be learned from this interpretive feat is that no one can tenably accuse the IBWC of stodginess or slavish literalism in acting upon its treaty mandate. ${ }^{203}$

More recently, IBWC Minute 308 recognized Mexican minimum water needs of 243,213 acre-feet stored in the Rio Grande international reservoirs, to supply Mexican citizens for domestic and municipal uses for ten months. ${ }^{204}$ This action on the part of the IBWC represents the second time it has acknowledged Mexico's right to a "critical supply" of water. ${ }^{205}$ Judging from the foregoing, the United States appears firmly committed to resolving the current water dispute within the framework of the 1944 Water Treaty and the IBWC. $^{206}$

\section{KEY PRECEDENTS INTERPRETING THE 1944 WATER TREATY}

It is undisputed that under the 1944 Water Treaty Mexico owes water to the United States. The essential issue is whether the treaty provides the necessary means for the resolution of the current water dispute. The first question to be asked is why, in a treaty which speaks of allotments in terms of halves and thirds, would there be two provisions that speak in the language of hard numbers? The answer is found by recognizing the scope of the treaty as a whole: it does not deal directly with any of the tributaries to the principal rivers named therein, but does so only indirectly insofar as those same tributaries are the sources of the water actually flowing in the Tijuana and Colorado Rivers and Rio Grande. ${ }^{207}$ If the treaty had spoken of allotments

202. Interview with Jorge Vargas, Professor of Law, University of San Diego School of Law, in San Diego, Cal. (Aug. 21, 2002).

203. But that is the very criticism most often leveled against it. See generally Mumme, supra note 46.

204. Minute 308, supra note 67, at 2.

205. See Minute 293, supra note 97.

206. See Kelly \& Chapman, supra note 82, at 2 (arguing that a "standoff over interpretation of the 1944 Treaty isn't going to solve any problems, and neither will repeated demands for impractical actions - for example, that Mexico divert all its water supplies in the Rio Bravo [Rio Grande] basin toward debt repayment.").

207. That is to say, the 1944 Water Treaty divides the waters of the three international streams but effects the division by reference to inflows from those streams' internal tributaries. See 1944 Water Treaty, supra note 2, at 1225-27, 1237, 1249. 
only in terms of proportions, then neither signatory nation would have had any obligation to deliver water to the other. One country might dam a tributary so that only a trickle of water flowed into a shared river, in which case the other country could then make its claim only for a portion of that trickle. ${ }^{208} \mathrm{By}$ inserting absolute minimums as part of the proportional division of waters covered by the treaty, an insurance against greedy damming was thereby made ${ }^{209}$ It was in the use of these absolute minimum guaranteed water flows that the treaty struck upon new ground. Whereas in the past a down-river nation might have expected little more than a trickle, now a precedent was set for up-river nations to ensure that their downstream neighbors received a greater portion of the river's water. ${ }^{210}$ In light of the construction of the

208. During the Senate hearings prior to ratification, several Texas water officials stated their belief that, without the treaty, the flow from the Rio Grande would be seriously diminished due to Mexican damming of tributaries for irrigation. See, e.g., statement of L. H. Ramey, General Manager, Hidalgo County Water Control and Improvement District No. 6, Mission Tex.:

The farmers and grove owners of this district fully realize that the continued diversion of the waters of the Rio Grande by Mexico as well as the impounding and diversion of waters by upstream development on the American side of the river is slowly but surely taking away from them the water that is so necessary to save their investments and allow them to continue the production of the crops that are so well adapted to this area.

Hearings, supra note 15, at 1609 . Also particularly telling is a subsequent exchange between the chairman of the Foreign Relations Committee, Tom Connolly (a Texan and strong supporter of ratification) and Mr. Ramey:

The Chairman. If these dams and other dams were constructed on these tributaries and the Mexicans used the water for irrigation, the supply for the Rio Grande would be very materially reduced, would it not?

Mr. Ramey. It would, and that is our great fear now: that water that has been coming from the Mexican tributaries is now to be cut off and not made available to the Rio Grande.

The Chairman. Your fear and the fear of the people in the valley is, irrespective of any additional water to be secured under this treaty, that Mexico may appropriate the major portion of the waters now flowing into the Rio Grande and use them on the Mexican side, thereby destroying or impairing-I will not say "destroying"-materially impairing your economy, so that you could not keep up even your present development, to say nothing of expansion.

Mr. Ramey. That is true, sir.

Id. at 1613 .

209. This conclusion follows necessarily, for, if the treaty provided no minimum guarantees, but instead permitted each country to use one-half of the actual flow of the Rio Grande, the upper-riparian country could fully utilize its Rio Grande tributaries without regard to the consequent negative effect on the flow of the Rio Grande. See also supra note 186.

210. It is somewhat amusing to note in light of recent denunciations of the treaty for its inequity that, at the time of its ratification, it was hailed as visionary and as a standard for future similar arrangements. See Timm, supra note 26, at 292 ("[The Treaty] is more than a mere division of water between the two countries: it provides the administrative machinery and the principles for international cooperation in the development of these water resources. As such, it may well be taken as a model for future treaties governing international steams."). 
Prior to the 1944 Water Treaty, the United States held that international law permitted an upstream nation to use the waters of a river flowing through its national territories to the fullest extent it desired. As a consequence, downstream nations would have no right against upstream nations for a more equitable sharing of a river's flow. This position, as applied in the United States, became known as the Harmon Doctrine, after the American Attorney General who first propounded it in 1895. Harmon was writing in response to a State Department request for a legal opinion concerning Mexican Minister Romero's protest over American use of the Rio Grande and Colorado River flows, which was harming Mexican users along the border. Romero argued that the citizens of El Paso del Norte had been using the water of the Rio Grande for over 300 years, and therefore deserved some protection against excessive American consumption. 21 OPS. ATT'Y GEN. 274, 276 (1895). After dispensing with Mexican claims based upon interpretations of the Treaty of Guadalupe Hidalgo, supra note 10, and the Gadsden Purchase, supra note 12, Harmon addressed directly the Mexican contention that the United States was bound to use the Rio Grande and Colorado River, irrespective of any treaty, in an equitable manner: "The fundamental principle of international law is the absolute sovereignty of every nation, as against all others, within its own territory." 21 OPS. ATT'Y GEN. at 281 . He went on to cite Chief Justice Marshall as authority for the proposition that any restriction upon a State's sovereignty must come from the State itself, through treaty or other statute, and cannot be imposed upon it by some external source. Id. at 281-82. The Attorney General noted that Mexico did not allege any "wantonness or wastefulness" on the part of the United States; therefore, "the question should be decided as one of policy only, because, in my opinion, the rules, principles, and precedents of international law impose no liability or obligation upon the United States." Id. at 283.

This position, viz that the United States was not bound by law to share equitably with Mexico the flows of the Rio Grande and Colorado River but could do so without prejudice to itself out of respect for binational comity, recurs repeatedly in the water disputes of the two countries prior to the 1944 Water Treaty. In a State Department note to Mexican charge d'affaires Gamboa prior to the 1906 Rio Grande Convention, Secretary Adee noted:

A careful examination of the law of nations on the subject has failed to disclose any settled and recognized right created by the law of nations by which it could be held that the diversion of the waters of an international boundary stream for the purpose of irrigating lands on one side of the boundary stream and which would have the effect to deprive lands on the other side of the boundary of water for irrigation purposes would be a violation of any established principle of international law.

Simsarian, supra note 14, at 43. In Article V of the 1906 Rio Grande Convention, both parties expressed the understanding that the United States was providing Mexico 60,000 acre-feet of water annually out of the interests of international comity only. 1906 Rio Grande Convention, supra note 17, at 2955. The position that the Harmon Doctrine "was disregarded in the first United States treaty to be signed after its formulation," 5 ALBERT E. UTTON, WATERS AND WATER RIGHTS \$ 49.03(a) (Lexis L. Publ'g 1991) (1967) (referring to the 1906 Rio Grande Convention), is off the mark. The United States decided to act in spite of the privileges it was accorded under the Harmon Doctrine and merely waived those rights for the time being while explicitly reserving them for future use. See generally Jacob Austin, Canadian-United State Practice and Theory respecting the International Law of Rivers: A Study of the History and Influence of the Harmon Doctrine, 37 CAN. B. REV. 393 (1959). "From [the time of Attorney General Harmon's opinion,] the United States firmly adhered to the principles of the Harmon doctrine as firmly established international law and the doctrine played a very full role in protecting the interests of the United States.... It may well be that this doctrine still expresses the views of the United States." Id. at 408 (written more than a decade after the ratification of the 1944 Water Treaty).

Herbert Hoover, then the Federal Representative and Chairman of the Colorado River Commission, which was to draw a compact regulating the use of the Colorado River among the 
Hoover and Imperial Dams along the Colorado River and Mexico's multiple dams along the Rio Conchos, ${ }^{211}$ the treaty's imposition of the now muchmaligned baselines is prescient.

A common criticism of the treaty is that it fails to define "extraordinary drought." That is true ${ }^{212}$; but no one is arguing that an extraordinary drought is not now besetting the Rio Grande Basin. The nub is not "What is drought?"

states, made reference to the Harmon Doctrine in his letter transmitting the agreed upon compact to the House of Representatives. He impliedly affirmed the substance of that doctrine, but advised that "it was not beyond the bounds of possibility that, as a matter of international comity, a treaty or agreement might at some time be entered into by the two nations which would establish some valid rights to the irrigation of these Mexican lands . ..." H.R. DoC. No. 67-605, at 5 (1923) (emphasis added).

In the Report to Congress of the International Water Commission, the U.S. Section noted in its statement replying to the Mexican claim that the Colorado river was an international watercourse and therefore had to be treated as a "single geographic unit," that the 1906 Rio Grande Convention water provision "was not to be considered as involving any legal obligation on the part of the United States to provide water for Mexico, [instead] it was done as an act of comity only." H.R. DOC. No. 71-359, at 5 (1929). It also reaffirmed the American adherence to the Harmon Doctrine: "the jurisdiction of a nation within its own territory and over its own resources is necessarily exclusive and absolute and susceptible only of self-imposed limitations. ..."Id. at 14. In response to the Mexican protest against U.S. plans for construction of the Boulder Dam along the Colorado River, the U.S. Section responded that it had "no knowledge of any treaty or other obligation of the United States which would restrict its act on the Colorado within its own boundaries," but that the American Section would "recommend the granting to Mexico, as an act of comity and friendship, but not as a right, the largest amount of water which it had ever taken in any one year." Id. at 8 (emphasis added).

Responding to California objections to the 1944 Water Treaty based upon the Harmon Doctrine, then Under Secretary of State Dean Acheson noted "this is hardly the kind of legal doctrine that can be seriously urged in these times." Hearings, supra note 15, at 1762. Jean Breitenstein, attorney speaking for six of the seven Colorado Basin states supporting the treaty, noted in the same hearing that the Supreme Court of the United States had refused to recognize the Harmon Doctrine as between states. Id. at 1539. See the discussion of Kansas v. Colorado and related cases, supra note 15.

The current Mexican position as to whether the Harmon Doctrine has any continuing authority is clear: "The defeat of the Harmon Doctrine-mentioned so often when talking about the International Law of international watercourses-has as an inevitable corollary in the shared responsibility of the states along any course of water and this is not only true with respect to the fair distribution and the different reasonable uses of the water of these international watercourses." SYMPOSIUM, supra note 137, at 15 (quote from Alberto Szekely, Advisor to the Mexican Secretary of Foreign Relations).

Whether the 1944 Water Treaty in fact abrogated the Harmon Doctrine is unclear, especially considering the U.S.-Mexico dispute over the salinity level of the Colorado River. See infra Part V.A.

211. Most of the water of the Rio Conchos is diverted in Mexico for crop irrigation or for municipal uses in cities such as Ciudad Chihuahua and Ciudad Juárez. Althaus, supra note 2.

212. Given that the present drought, although severe, is by no means unprecedented-even if its effects be severe-it is somewhat surprising that there was little dispute over Mexico's availing itself of its Article 4(B) privilege of extending its debt payment time period, for to have done so meant at least a tacit recognition by the IBWC that the present drought is "extraordinary" within the meaning of the 1944 Water Treaty. See supra Part II.C. See also UPDATE, supra note 65 , at 4. 
but "What is to be done about it?" Another lacuna is the treaty's failure to say what must be done if Mexico's water debt extends beyond two consecutive accounting periods. In the absence of an explicit provision, it is only natural to refer to Article 24(d) and its charging of the IBWC with a series of mandates, including the duty to "settle all differences that may arise between the two Governments with respect to the interpretation or application of this Treaty, subject to the approval of the two Governments"- the language of an omnibus clause. The apparent intention of the treaty's drafters was to refer all disputes to the IBWC. ${ }^{213}$ Any trepidation caused by the specter of an omnipotent IBWC run rampant is quickly dispelled by reference to IBWC Minute $242^{214}$ and the Colorado River salinity controversy.

\section{A. Colorado River Salinity}

From the ratification of the treaty until 1961, the United States had no difficulty in assuring that Mexico received its 1.5 million acre-feet of water annually from the Colorado River as mandated by Article $10 .^{215}$ In 1961, the Wellton-Mohawk Irrigation Pumping Project began in southern Arizona, its purpose the supplying of water to Arizona users through the reclamation of waters contained in underground aquifers. ${ }^{216}$ The drainage from the project, when combined with the Colorado River, initially created a salinity level of 6,000 parts per million (ppm) in the river water delivered to Mexico. ${ }^{217}$ This brought the average salinity level of treaty deliveries to almost $1,500 \mathrm{ppm}$, an increase from the pre-drainage average of nearly one hundred percent. ${ }^{218}$ The Mexican government became concerned that such a high salinity level would adversely affect the agriculture of the Mexicali (Mexican Imperial) Valley. ${ }^{219}$

Initially, the United States contended that the salinity level of the Colorado River water delivered to Mexico was immaterial under the treaty, as Article 11(a) provides that the delivered water "shall be made up of the waters of the said river, whatever their origin, subject to the provisions [concerning water deliveries]." 220 Mexico claimed that "the delivery of water that is

213. See Timm, supra note 26, at 291.

214. Permanent and Definitive Solution to the International Problem of the Salinity of the Colorado River, Aug. 30, 1973, U.S.-Mex., 24 U.S.T. 1968, available at http://www.ibwc.state.gov/html/foreign_affairs.html (last visited Nov. 12, 2003) [hereinafter Minute 242].

215. Brownell \& Eaton, supra note 63, at 255.

216. Id.

217. Id. at 256.

218. Id.

219. Id.

220. 1944 Water Treaty, supra note 2, at 1238. In their article, Brownell and Eaton state that one of the secondary issues that proved an initial stumbling block in the negotiations leading up to Minute 242 was the question of whether Mexico was legally obligated to accept Wellton-Mohawk drainage as part of treaty deliveries. Brownell \& Eaton, supra note 63, at 260. Minute 242 makes no definitive interpretation as to what either party is legally entitled to 
do. Perhaps both sides let the issue drop to avoid recourse to the International Court of Justice.

The issue of salinity of the Colorado River water the United States was to provide Mexico proved ostensibly to be one of greatest obstacles to the 1944 Water Treaty's ratification by the Senate. When asked by Senator Downey of California (an ardent opponent of the treaty) whether any ambiguities in the treaty could be resolved by an exchange of notes between the two governments, Under Secretary of State Dean Acheson responded "I do not believe there are any ambiguities or that the committee would so claim." Hearings, supra note 15, at 1764 . The following exchange between the two is illuminating:

Senator Downey. ... One of the interpretations given by the State Department is that to the full extent of the return flow Mexico must take that and credit it upon our 1,500,000 acre-feet, and she must take that water, even though it is unusable. .. ?

Mr. Acheson. Senator, I do not think there is the slightest doubt about the matter you raise. ... It seems to me that in three places, in articles 10 and 11 of the treaty, they have made that abundantly clear.

...

So three times it has been made clear in the treaty that what Mexico gets is $1,500,000$ acre-feet of water from any and all sources, for any purpose whatsoever, and whatever the origin.

Senator Downey. Even though it comes from seepage and drainage, and even though it becomes so saline that it is not usable by Mexico?

Mr. Acheson. Those are the plain words of the treaty, Senator.

Senator Downey. And you are here stating, as a representative of the State Department, that is your understanding of the treaty, and you think it is the understanding of the Mexican Government; is that right?

Mr. Acheson. I state that the plain language of the treaty means exactly what it says, and that there cannot be any question or doubt about it.

Id. at 1764-65 (emphasis added). Senator Millikin, a supporter of the treaty, subsequently asked Acheson whether he knew of any "international principle" that would require the United States to provide Mexico water of a certain salinity level. Acheson responded no. Id. at 1770 . Acheson further clarified his position upon critical questioning by Senator Murdock of Utah:

What I tried to make clear was that under the treaty, as stated very clearly in the treaty, the water which is allocated to Mexico is from any and all sources in the river, that the amount of 1,500,000 acre-feet is the limit of Mexico's demands on the river for any purpose whatever, and that such waters as Mexico gets shall be made up from the waters of such river, whatever their origin. My view is that the 1,500,000 acre-feet of water described is from any and all sources, for any purpose whatever, and whatever its origin. That is what the treaty calls for.

Id. at 1777 (emphasis added). Referring to the pertinent portions of the treaty, the State Department statement submitted to the Committee a few days after Acheson's appearance underscored his interpretation, arguing that the "purpose of these clauses, obviously, is to insure credit to the United States for all drainage, return flows, and other excess or surplus flows originating in the United States, and to obviate all questions as to the quality of the water." Id. at 1803.

How to account for the volte-face in the American position, and in fewer than thirty years? Brownell and Eaton make mention of the 1966 Helsinki Rules on the Uses of International Rivers as having provided guidance to the negotiators (even though the rules are not a treaty and have no binding force). Brownell \& Eaton, supra, at 259 . Article IX of the Helsinki Rules defines "water pollution" as "any detrimental change resulting from human conduct in the natural composition, content, or quality of the waters of an international drainage basin." REPORT OF THE FIFTY-SECOND CONFERENCE OF THE INT'L L. ASS'N, HELSINKI RULES ON THE USES OF THE WATERS OF INTERNATIONAL RIVERS, 52 I.L.A. 477, 494 (1967). Subsection 1 of Article $X$ requires that a State both prevent any new form of water pollution in the 
harmful for the purposes stated in the Treaty constitutes a violation of the Treaty." ${ }^{221}$ The bugaboo of recourse to the International Court of Justice was raised by both sides. ${ }^{222}$ The matter was instead resolved in accord with Article 24(d) and Minute 242. Before the matter could be agreeably resolved, however, certain disputed issues relating to a final solution had first to be negotiated. ${ }^{223}$

In immediate response to the Mexican protest, the U.S. State Department reassembled the Committee of Fourteen (which had first been formed prior to final negotiation of the 1944 Water Treaty) and reduced the salinity of the river through "selective pumping" of the Wellton-Mohawk aquifer. ${ }^{224}$ Mexico pushed for a definitive solution, to which the United States was amenable, but several ancillary issues were presented which threatened to derail the salinity-related negotiations. ${ }^{225}$ Chief among these was Mexico's own groundwater pumping project on the San Luis Mesa immediately south of the border, which raised the issue of the treaty's silence as to groundwater exploitation by the signatories. ${ }^{226}$ The Mexican project was especially offensive to American interests as it threatened to absorb U.S. groundwater and to impede U.S. treaty deliveries. ${ }^{227}$ Of considerable importance was the Mexican claim to damages done to Mexicali farmers as a result of the excessively saline treaty deliveries. ${ }^{228}$ The challenge thus posed to the IBWC and both countries by the salinity controversy was of a magnitude similar to that of the current water dispute; nonetheless, an agreement was reached.

basin and take all reasonable measures to reduce existing pollution. Id. at 496-97. Article XI requires an offending State "to cease the wrongful conduct and compensate the injured co-basin state for the injury that has been caused to it." Id. at 501. Under the Helsinki framework, and contrary to the Acheson interpretation of the 1944 Water Treaty, the United States would have had to ameliorate the effects of the Wellton-Mohawk Project, as well as compensate Mexico for any damage done to its territory on account of increased salinity levels of treaty water.

It is at least arguable that, during the Colorado salinity dispute, the United States might have had a good argument that it could force Mexico to accept water from any source and use the IBWC as the means. On the other hand, even if the Acheson interpretation of the treaty was also the Mexican interpretation at the time of ratification, international law at the time of the dispute had moved much closer to the Mexican position that no downstream state should have to accept water harmful to its territory. Although the United States had never fully adopted the equitable use doctrine for the governing of international watercourses, it had since the 1906 Rio Grande Convention with Mexico acted as if it did, while officially claiming a motivation of international comity.

221. Brownell \& Eaton, supra note 63, at 256.

222. Id. at 259.

223. Id. at 259-63.

224. Id. at 256. The stopgap measures undertaken by the United States were agreed to in IBWC Minute 218, available at http://www.ibwc.state.gov/htmlfforeign_affairs.html (last visited Nov. 12, 2003).

225. Brownell \& Eaton, supra note 63, at 260-63.

226. Id. at 261.

227. Id.

228. Id. at 262. 
Minute 242, the "permanent and definitive solution" to the controversy, authorized the construction of a desalting plant to treat the drainage brine created by the Wellton-Mohawk project and thereby reduce the salinity of Colorado River water delivered to Mexico to $115 \mathrm{ppm} \pm 30 \mathrm{ppm}$ (a level the water would have had without the Wellton-Mohawk project). ${ }^{229}$ The United States refused to reduce the salinity of its treaty deliveries through the addition of water derived up-river from Wellton-Mohawk, as this dilution would have cut into the available supplies of the Basin states, and of that the Committee of Fourteen would have none. ${ }^{230}$ The United States also agreed to have constructed at its own expense through Mexican territory a cement drainage ditch to carry away excess brine to the Gulf of California. ${ }^{231}$ Implicitly recognizing one of the omissions of the treaty, the Minute established a temporary limit on the pumping of groundwater to within five miles of the border. ${ }^{232}$ Last of all, the United States promised to reimburse Mexicali farmers whose fields had been damaged by highly saline treaty water. ${ }^{233}$

Two important lessons can be learned from the negotiations leading to Minute 242 and the Minute itself. First, despite ambiguities, the treaty was equitably applied by the IBWC through its Article 24 interpretive power. Mexico had originally asked for a salinity level equal to that of water up-river from Wellton-Mohawk, whereas the United States had sought what was termed an "equivalent salt balance." 234 The final agreement settled upon a ppm level reflecting a rough median between the two extremes. ${ }^{235}$ Such an attitude of compromise may well come in handy in negotiating a solution to the present Rio Grande controversy.

Second, the final agreement stands as a testament to the expediency of the IBWC in resolving disputes, just as Article 24 envisions. Both Mexico and the United States could have assuredly sought recourse to other interna-

229. Minute 242, supra note 214, at 1972; Brownell \& Eaton, supra note 63, at 269. An analogy can easily be drawn between the U.S. expenditures for the desalting plant and proposed measures today for Mexico to improve its water conservation programs and hydraulic infrastructure efficiency.

230. Brownell \& Eaton, supra note 63 , at $263 \mathrm{n} .24,265$. One wonders if during a hypothetical treaty renegotiation today whether the Committee of Fourteen would be any more responsive to Mexican interests if an increase in Colorado treaty deliveries were proposed, especially in light of Basin development subsequent to Minute 242.

231. Minute 242, supra note 174, at 1974-75. The provision forbids the United States from discharging any "radioactive material or nuclear waste" in the channel. Id at 1975. That such is mentioned in the Minute gives a good insight into the strength and candor of the parties' mutual relationship.

232. Id. No comprehensive groundwater exploitation agreement has been reached. Mumme, Reinventing the International Boundary and Water Commission, supra note 46, at 4.

233. Minute 242, supra note 214, at 1976 . Interestingly, Brownell and Eaton note that the extent of, or even the existence of, damage to the Mexicali farmers caused by excessively saline treaty deliveries was a matter of some dispute among the parties' experts. Brownell \& Eaton, supra note 63, at 262.

234. Brownell \& Eaton, supra note 63, at 268-69.

235. Id. at 269. 
tional bodies, such as the International Court of Justice, ${ }^{236}$ but to have done so would have just as assuredly reduced the role of the IBWC to that of a quaint and emasculated distraction. The decisions normally reserved to the Commission would forever have a haze of uncertainty about them, as a de facto road of appeal to a separate international tribunal could be used by one of the parties to overturn an IBWC directive, or at the very least to justify brazen noncompliance. Part of the genius of the treaty is that it established what amounts to a bilateral commission, thus assuring that it would be always in the field and "close to the action," but invests it with the responsibilities and privileges of an international body. Both sides' fears of its forced obsolescence might explain why the compromises of Minute 242, especially as to groundwater exploitation and the means for salinity reduction, were agreed to. ${ }^{237}$ Lamentably, that very willingness to compromise in order to preserve the ordinary channels of dispute resolution mandated by the treaty is lacking from the present controversy.

\section{B. Minute 308}

Another excellent precedent for dispute resolution by the IBWC operating under its Article 24 authority exists in the guise of Minute 308. This agreement came after particularly intense criticism by Texas water stakeholders and politicians directed against Mexico's allegedly halfhearted attempts at meeting its growing water debt. ${ }^{238}$ The Minute followed an earlier agreement for Mexico to begin partial transfers to be credited against its total water debt. ${ }^{239}$ The U.S. Section of the IBWC was able to win from Mexico a

236. Recall that Article 24(d) allows for "diplomatic channels" and extrinsic "general or special agreements" to be used to resolve disputes arising under the treaty when the IBWC is unable to find a solution. 1944 Water Treaty, supra note 2, at 1256.

237. This fear may also explain the desire to avoid recourse to the International Court of Justice or some other independent arbitral tribunal. See Brownell \& Eaton, supra note 63, at 259.

238. See, e.g., Althaus, supra note 2 ("Desperate Texas farmers in the Rio Grande Valley, as well as politicians from Gov. Rick Perry to U.S. Sen. Kay Bailey Hutchison, have insisted that Mexico has enough water to at least begin paying what it owes."); Rennie, supra note 110 ("Texas farmers and politicians accuse Mexico of hoarding water, producing satellite photographs of lush green fields and brimming reservoirs on the Mexican side of the border."); Weiner, supra note 61 (quoting a Texas water official, "Mexico has 'shorted us, and they shorted their own growers twice as much." ").

239. See Minute 307: Partial Coverage of Allocation of the Rio Grande Treaty Tributary Water Deficit from Fort Quitman to Falcon Dam, March 16, 2001, U.S.-Mex, at http://www.ibwc.state.gov/html/ foreign_affairs.html (last visited Nov. 12, 2003) [hereinafter Minute 307]. In response to a request by President Bush for Mexico to make a partial payment on its debt, Mexico agreed to transfer 600,000 acre-feet by July 31,2001 . Id. at 2 . Point 3 of the Minute reaffirmed both Governments' commitment to cooperate on drought and growth management. $I d$. at 3. By February of 2002, more than six months after the deadline imposed by Minute 307 for the treaty deliveries, Mexico had made available only 426,544 acre-feet. UPDATE, supra note 65 , at 6. 
promise to make 90,000 acre-feet immediately available to the United States, subject to several conditions dealing with how Mexico's actual inflows into the international reservoirs between the date of the agreement and the conclusion of the then-current accounting cycle in October, 2002, would be credited against its present transfer. ${ }^{240}$ Almost as important as Mexico's promise to transfer water was the recognition by the United States in observation point 5 of a critical supply of water (243,213 acre-feet) which Mexico required to meet the needs of its Rio Grande communities for the following ten months, and a promise by the United States to make available to Mexico from waters in the international reservoirs allotted to the United States sufficient amounts for Mexico to maintain its critical supply. ${ }^{241}$ The Commissioners took note of Mexico's intention to modernize its hydraulic infrastructure and of a promised Mexican investment of $\$ 1.5$ billion pesos in the next four years. ${ }^{242}$ Both sides reaffirmed their commitment to assigning "the highest priority" toward meeting their treaty obligations. ${ }^{243}$ The Commissioners also expressed the desires of their Governments to convene a bi-national summit to discuss the prudent management of the Rio Grande Basin. ${ }^{244}$ Practically speaking, the Minute's most important provision is point 3 , which states that the two Governments "will continue discussions . . . concerning the [water] deficit," i.e. the matter was put off until the conclusion of the then-current accounting cycle. ${ }^{245}$

In light of U.S. water stakeholders' vigorous attacks, the accommodating stance assumed by the United States in Minute 308 is striking. The 90,000 acre-feet transfer represents six percent of Mexico's total debt, an offer that was not well received by Texas growers. ${ }^{246}$ The Mexican transfer is all the more amazing in that the United States guaranteed that it would replenish what was taken from Mexican holdings if the transfer proved to draw upon Mexico's critical supply. ${ }^{247}$ This conciliatory stance is best understood as an

240. Minute 308, supra note 67, at 2 . The Minute observation (A)(a)(3) notes that if, by the end of the accounting cycle Mexican inflows have replaced the 90,000 acre-foot transfer, the United States will account in Mexico's favor the "losses attributed to conveyance of this volume to the international dams" of 28,845 acre-feet, $i d$., a tacit admission of the Mexican argument that releases from its dams are counterproductive given the high loss of water through evaporation and seepage. Nevertheless, it is remarkable that the United States should bear the cost of Mexican hydraulic inefficiency incurred by Mexico's late debt payments to the United States.

241. Id.

242. Id.

243. Id.

244. Id. at 4.

245. Id.

246. Dellios, supra note 9. See Boudreaux, supra note 3 (quoting a Texan water official: "What's so frustrating about this, they could have given us this water a month ago when it would have helped more."). Governor Perry of Texas called upon Mexico to commit to a "regular schedule" of debt payments. Id.

247. Minute 308, supra note 67 , at 2. 
attempt to prevent Mexican recourse to an international arbitral body independent of the treaty and the IBWC, not necessarily because Mexico has the better legal argument, but for the practical concerns regarding treaty interpretation and enforcement already discussed. At the very least, American stakeholders could take heart in the symbolic value of Mexico's payment as a tacit Mexican affirmation of its debt under the treaty and its discarding (for the moment) of any serious intention to renegotiate. Moreover, the Minute as a whole exemplified the IBWC using its Article 24 power to good effect: though the treaty is silent as to the manner of Mexican debt payment, the IBWC fairly implemented the framework established in Minute 234 to devise a stopgap measure keeping both sides at bay for the time being.

Despite the recent successes of the IBWC in stanching the wounds of irate Texas stakeholders and calming the pricked nationalism of northern Mexico farmers and politicians, tensions on both sides will overwhelm the Commission and the treaty unless a definitive and final solution is reached as to Mexico's water debt. The bargaining positions of both sides, their legal worth, and a likely compromise answer, are the subject of the following and concluding portion of this Comment.

\section{SOLUTIONS}

\section{A. Mexican Proposals}

Mexico must first answer the threshold question: shall it ask for a renegotiation of the treaty? Certainly the United States wants to exact from Mexico a definitive answer one way or the other. Even if the treaty can be set aside and the same issues dealt with under a replacement, the crux of the matter is whether it would be in Mexico's best interest to do so. Those on the Mexican side who insist that the treaty is inequitable must offer some proof of the inequities contained in it and how they might be righted under a replacement. But if by inequity it is meant that the United States has won for itself the better part of the deal, there will be little international sympathy for Mexico's position. One cannot both reject the treaty because the United States won for itself a favorable legal regime and accept the nation-state system. In the balance of power, there are some nations that will weigh heavier than others, but no tribunal is willing to put a thumb on the scale merely because the balance is not even.

Mexico might choose to draw the attention of the United States to Mexico's Article 4(B) obligation, the root cause of the dispute. Recall that during the original treaty negotiations, Mexico had wanted no absolute baseline but instead the right for each country to exploit fully its own tributaries to the Rio Grande. The United States, seeing that Texas agriculture south of Fort Quitman was wholly dependent upon the Rio Grande flows, and that seventy percent of those flows came from Mexican tributaries, knew that a treaty without an absolute baseline would be an invitation for Mexico to 
exploit its own tributaries, leaving Texas farmers in the lurch. ${ }^{248}$ Nowadays, the United States could note that Mexico's construction of multiple dams along the Rio Conchos has done more than a little to reduce that tributary's natural flow into the Rio Grande. ${ }^{249}$

Mexico might claim that the current drought has exposed the weaknesses of the treaty and has made its provisions work an inequity. One can certainly fault both sides for inadequate drought planning, but the treaty makes explicit references to "extraordinary drought" and what is to be done when it occurs. Naturally, the treaty drafters would leave a good deal of gray when deciding how water allotments ought to be affected during drought, for it was and is an innately unsettling issue because it reminds both sides of how limited the resource is. If the treaty were to be abandoned, what would happen to those American stakeholders who have based their livelihood on the fulfillment of Mexico's treaty obligations? Without doubt Mexico's abrogation of its Article 4(B) debt would work just as great an inequity on South Texas as would the Article's fanatical and merciless application by the United States upon northern Mexico. Additionally, the question of what should be done when the Mexican debt extends over two consecutive accounting cycles poses a problem best resolved by interpretation of the treaty, not its renegotiation.

Lastly, Mexico might ask for a reduction in its water debt. Given the extreme toll the current drought has taken on water supplies, Mexico can argue forcefully that its debt ought to be reduced proportionately in accord with the reduction in consumptive use by its stakeholders, a option afforded the United States in its treaty obligation over the Colorado River. This position runs up against several difficulties:

(1) Any change in the amount owed under Article 4(B) of the treaty could be interpreted as an act extending beyond the IBWC interpretive power granted to it by Article 24 .

(2) Unlike Mexico, where water is owned by the federal government, the United States must defer in part to the water compacts which the states have formed to regulate consumption among themselves. ${ }^{250}$ For example, during the negotiations leading to Minute 242, the Committee of Fourteen made it clear that it did not want the United States resolving the

248. Timm, supra note 26 , at 285.

249. See Althaus, supra note 2 (detailing how much of the flow of the Rio Conchos, a major Mexican tributary of the Rio Grande, is caught by seven dams and diverted for agricultural or municipal use).

250. When asked by Senator Hayden whether the 1944 Water Treaty "if approved, [would] take precedence over all existing Federal and State statutes and all instruments relating to the Colorado River and its tributaries," Clayton of the IBC responded no. Hearings, supra note 15, at 129 . 
salinity dispute by using any of the water allocated from the Colorado to the Basin states. ${ }^{251}$ Understandably, then, some mechanism was required in the treaty to allow the United States to reduce its obligation, as it could not harness the full supply of water flowing through the river to fulfill its Article 10 duty. In contrast, for Mexico any concession it grants to use water from the Rio Conchos or any other river is revocable. $^{252}$

(3) Given the history of water use in northern Mexico and the internal biases of the Mexican water legal regime, as long as there remains any debt, a controversy over its payment will ensue. This is so because of the Mexican system's anti-conservation dynamic: as there is little incentive to conserve water or to change irrigation techniques, and because more water means less need to renovate hydraulic infrastructure, the end result will always be Mexican over-consumption and subsequent debt, though a debt proportionately smaller than today's. Moreover, the symbolic onus of a continuing "Mexican water debt" would vitiate any dividends in AngloMexican goodwill reaped from a debt reduction.

Despite the loud protests from certain Mexican commentators and politicians and calls for renegotiation, the line from Mexico City has been a consistent one: we will pay. ${ }^{253}$ The reason behind Mexico's commitment to meeting its treaty obligations and its intention not to renegotiate is found in the Mexican annual 1.5 million acre-feet allotment from the Colorado River. Were the treaty to be renegotiated, the United States, prodded by Colorado Basin states, would push hard for a reduction in Mexico's allotment. ${ }^{254}$ It would be exceptionally difficult for Mexico to demand a reduction or elimination of its debt and obligation under Article 4(B) while refusing to budge over its Article 10(a) allotment. ${ }^{255}$ Indeed, the argument of obsolescence used

251. Brownell \& Eaton, supra note 63, at 263 n.24.

252. See Water Act, supra note 86, at art. 27 (IV).

253. See Kraul, supra note 4 (quoting Mexican President Vicente Fox promising "to comply completely with Mexico's international obligations, reducing the deficit of deliveries to the United States and guaranteeing at the same time supplies to border populations and attention to the interests of Mexican farmers").

254. California would be most anxious to have Mexico's entitlement decreased, in light of the Interior Secretary's recent decision drastically to reduce California's traditional surplus allotment from the Colorado River under the Colorado Compact. See Michael Gardner, LastMinute Water Deal Sinks, SAN Diego UnION TriB., Jan. 1, 2003, at A1; Michael Gardner, Dampened Hopes, SAN DIEGO UNION TRIB., Jan. 2, 2003, at A1.

255. Perhaps the reason for Mexico's dragging of its feet now is the hope of some future quid pro quo agreement should the United States fall behind in its Colorado River treaty obligations to Mexico, for which no provision is made in the 1944 Water Treaty. 
against Article 4(B) can be used just as effectively against Article 10(a): who would not concede that the Colorado River Basin states have seen their water requirements increase steadily over the last sixty years? ${ }^{256}$ For these reasons, Mexico ought to be chary about renegotiating. It should seek instead a solution worked out through the IBWC that preserves its existing Colorado River entitlements.

\section{B. U.S. Proposals}

It is in best interest of the United States to preserve the existing treaty and ensure that any solution to the current controversy be resolved within the framework established by it and the IBWC. The reasons why an extrinsic solution would be undesirable have already been discussed. From the U.S. point of view, the means for a resolution of the dispute already exist: Minute 234 provides what sources of water can be used by Mexico to pay its debt; Minute 242 established a strong precedent for seeking answers to disputes under the treaty through methods intrinsic to the treaty; Minutes 240 and 293 established American willingness to assure a critical supply of water for Mexican border communities irrespective of Mexico's current debt; and Minutes 307 and 308 began the tradition of the United States seeking irregular and partial goodwill payments by Mexico of its Article 4(B) debt. Moreover, the United States has urged the need and Mexico has responded to the calls for large capital investment in hydraulic infrastructure improvements. Both sides have also committed themselves to "smart-growth" and water conservation plans. The one thing remaining for the United States is to reach an agreement that extends beyond the ad hoc provisions of Minutes 307 and 308 and serves as a final solution to the current controversy, much the way Minute 242 ended the Colorado salinity dispute.

256. One controversy lying in the background concerns the California Imperial Irrigation District's recent decision to reline the All-American Canal so as to prevent water loss through seepage. Chris Kraul \& Tony Perry, Rift Runs Deep in Water War, L.A. TIMES, May 4, 2002, at A1. The seepage, amounting to two percent of the water transported through the canal, has served as lifeblood for Mexican agriculture located just across the border a few hundred yards from the leaking canal. Id. Mexico has built over 400 wells to capture the water and then to use it to irrigate 50,000 acres of farmland. Id. Mexico claims that the 1944 Water Treaty requires the United States to consult with Mexico before undertaking a project affecting water supplies. The relevant provision is found not in the 1944 Water Treaty but in Minute 242, which reads in part: "[T] he U.S. and Mexico shall consult with each other prior to undertaking any new development ... that may adversely affect the other country." Minute 242, supra note 214 , at 3. Mexico's position is precarious to say the least: (1) the natural interpretation of the provision deals with adverse effects upon the other nation's property or water, e.g. mining groundwater or flood damage, not water belonging to one country that by chance ends up in the other country; (2) the U.S. might concede the water to Mexico but demand that the water received be accounted in favor of the U.S. Colorado River obligation; (3) the U.S. might concede the water to Mexico but demand payment for it as in excess of treaty deliveries. 


\section{A Possible Compromise Acceptable to Both Sides}

The time is ripe for both sides to reach a final and definitive solution to the current controversy. ${ }^{257}$ Although it has been bandied about by some persons on the Mexican side, denunciation of the treaty appears not to be a viable option: there is no explicit provision for it in the 1944 Water Treaty, and it was the clear intention of the drafters that the treaty be perpetual. ${ }^{258}$ Second, the United States, unlike Mexico, is not free to rewrite water concessions at whim, as it must defer to the arrangements made by the several states inter sese. ${ }^{259}$ Third, any substantial change to the treaty would be considered an amendment, requiring the U.S. and Mexican Senates' approval, which cannot be counted upon. A permanent solution to the dispute must make note of the foregoing and incorporate the following elements.

\section{Affirmation of Mexico's water debt}

Mexico must make a solemn, definitive, and irrevocable affirmation of the treaty and of the debt it owes to the United States under Article 4(B), and an equally firm promise eventually to liquidate its debt. Such an avowal would eliminate the dichotomy that now exists between the Governments on the one hand, and the Mexican academy and politicians on the other. It would also serve to placate Texas farmers while putting the damper on the possibly greedy intentions of the Colorado Basin states for an increase in their own allotments at Mexico's expense.

This element of the solution is not, strictly speaking, a legal one, unless it be seen as a waiver on Mexico's part of the "diplomatic channels" and "general or special agreements" language found in Article 24(d) of the 1944

257. On January 10, 2003, the U.S. Department of State announced that Mexico had made a "firm commitment" to transfer 350,000 acre-feet of water by September 30, 2003. Both Mexico and the United States agreed to hold a joint summit to address how "to ensure a reliable and predictable water supply during both periods of scarcity and of abundant rainfall." Press Release, U.S. Department of State, United States and Mexico Agree on Delivery of Rio Grande Water (Jan. 10, 2003), at http://www.ibwc.state.gov/PAO/CURPRESS/CurPress2/waterunder standingStateweb.htm (last visited Nov. 12, 2003).

The U.S. Section of the IBWC announced April 3, 2003, that Mexico has transferred just over 250,000 acre-feet since October of 2002; its debt currently totals 1.37 million acre-feet. USIBWC Press Release, supra note 68 . These recent moves represent no departure from precedents established in Minutes 307 and 308.

258. "I might say that this treaty, like the 1906 treaty, is perpetual. It must be perpetual because the object of it is to define for all time the rights of the two nations in the waters of the international streams. On the Colorado, for instance, we would not want Mexico in 1980, when we have built up substantial uses in this country, to say 'Well, we do not want to abide by the treaty. Let us forget the thing and start over,' when they might be using 3,000,000 acre-feet from that river at that time." Hearings, supra note 15, at 123 (statement of Frank B. Clayton, IBC Counsel).

259. See infra note 267. 
Water Treaty. ${ }^{260}$ Frankly, Mexico would be unlikely to agree to a blanket waiver of that privilege, especially in light of the increasing likelihood that the United States might fail to meet its annual Colorado River treaty deliveries in the coming decade. If that were to happen, Mexico would be most desirous of using its option of adjudicating any dispute at the International Court of Justice to force the United States to a favorable settlement, as was the case in the Colorado River salinity dispute.

If the affirmation were to take the form of a waiver, it would most likely require the approval of the Mexican Senate as an amendment to the 1944 Water Treaty, ${ }^{261}$ although the U.S. Senate's approval would not be necessary, given that the rights of the United States would remain unchanged. These complications could be avoided merely by the insertion in an IBWC Minute of a clause saying the same thing without making mention of "waiver."

\section{Resolving the debt-cycle ambiguity}

The ambiguity now existing in Article 4(B)(c) as to the course to be taken when Mexico's debt extends over two consecutive accounting cycles must be definitively resolved by the IBWC through the exercise of its Article 24 interpretive power. The treaty simply states that Mexico may carry over any debt incurred in a five-year accounting cycle to the following cycle; since no mention is made of what to do about a Mexican debt extending over two cycles, one can infer that the drafters thought the occurrence unlikely. Nevertheless, the ambiguity falls within the "interpretation or application" power of the IBWC under Article 24(d). As such, any decision made by the IBWC under that provision would not be considered a de jure amendment to the treaty. ${ }^{262}$

The ideal solution to the ambiguity would be to extend the five-year accounting cycles as far into the future as is necessary to allow Mexico to pay off its debt, with due allowance made to avoid any Mexican foot-dragging. This would be seen as a goodwill gesture to Mexico by the United States. It would also be a natural and just interpretation of the treaty as it now stands.

260. 1944 Water Treaty, supra note 2, at 1256.

261. See MEX. ConsT. art. 89, $\S 10$ (stating that the powers and duties of the President of the Mexican Republic include "[c]onducting foreign policy and signing international treaties, submitting them to the Senate for approval").

262. It is conceivable that the IBWC and the two countries might manufacture a de facto amendment-meaning an "interpretation" of the treaty that radically alters the parties' rights formerly assumed thereunder — cloaked by the Article 24 interpretative power. This question raises the issue of the U.S. Supreme Court's role in treaty interpretation. See supra Part IV.A.3.c. It also presents a political issue beyond the scope of this Comment. 


\section{A schedule of water payments}

A definite and long-term schedule of regular water payments by Mexico must be agreed to. The current pattern of no payments until an emergency arrives is unacceptable, as it serves only to shorten tempers on both sides and make the subsequent payments appear either woefully inadequate or wrought away like a pound of flesh. If payments are regularly scheduled, then both sides can properly plan for and anticipate them. The assembling of a debtpayment schedule can be done within Article 24(d): the treaty explicitly provides for the accounting of a Mexican water debt, ${ }^{263}$ and there exists ample precedent in IBWC Minutes for arranging debt repayment. ${ }^{264}$ These precedents are important from the U.S. standpoint, for even if Mexico were later to claim that such debt-repayment scheduling exceeds the IBWC interpretative power under Article 24(d), the United States could counter by claiming that, because of the passage of time and the absence of any Mexican protest to past IBWC actions, Mexico would now be estopped from arguing otherwise. Moreover, as a debt repayment would be authorized under Article 24(d), neither country would need to seek the approval of its Senate; therefore, both could bypass criticisms from particular states.

In practical terms, a simple schedule is not sufficient. Any plan must also be sensitive to changes in climate, especially to drought. If the drought worsens, a particular payment by Mexico ought to be reduced accordingly. If, on the contrary, inflows increase, the next payment ought to be increased. But the guiding principle to the payment plan must not be, as it is now, how most efficiently to placate critics on both sides and buy more time, but rather to make an optimal schedule for Mexico's complete liquidation of its debt.

\section{Technical improvements, conservation, and planned growth}

In addition to encouraging Mexican investment in hydraulic infrastructure improvements and fostering a universal culture of conservation, both sides must agree to implement as soon as possible water-saving measures. It is not enough for the United States to carp on Mexico; it too must abide by its sermon and support hydraulic efficiency in south Texas. ${ }^{265}$ As long as both sides are actively engaged in capital outlays, the inevitable tax increases for stakeholders North and South will be more palatable.

In legal terms, any plans the IBWC might adopt that would require capital outlays on the part of the United States would have to be approved by

263. 1944 Water Treaty, supra note 2, at 1227.

264. See, e.g., Minute 234, supra note 102; Minute 307, supra note 239; Minute 308, supra note 67.

265. A water survey submitted to the Texas legislature in 2000 found that, with certain efficiency improvements, as much as 354,000 acre-feet of water could be saved. Nitze, supra note 7 , at 15 . 
the U.S. Congress, according to paragraph (a) of the supplementary protocol of the 1944 Water Treaty. ${ }^{266}$ Furthermore, the U.S. federal government cannot dictate to the several states, regardless of its existing treaty obligations, how they will manage their water resources within their own territories. ${ }^{267}$ Nevertheless, the groundwork for hydraulic infrastructure improvement, conservation measures, and planned growth programs can be laid by the IBWC; it has already made the first steps in this direction. ${ }^{268}$ One way to circumvent the spending problem is to have a third party make loans to large stakeholders in the Rio Grande Basin for efficiency and conservation improvements. ${ }^{269}$ The downside to this element of the comprehensive solution

266. "That no commitment for works to be built by the United States in whole or in part at its expense, or for expenditures by the United States, other than those specifically provided for in the treaty, shall be made . . . without the prior approval of the Congress of the United States." 1944 Water Treaty, supra note 2, at 1263-64 (emphasis added).

267. See paragraph (c) of the treaty's supplementary protocol: "That nothing in the treaty or protocol shall be construed as authorizing the Secretary of State of the United States, the Commissioner of the United States Section on the International Boundary and Water Commission, or the United States Section of said Commission, directly or indirectly to alter or control the distribution of water to users within the territorial limits of any of the individual states." Id. at 1265.

268. Recommendation 3 of Minute 307 states that the United States and Mexico "will work jointly to identify measures of cooperation on drought management and sustainable management of [the Rio Grande] basin." Minute 307, supra note 239, at 3. Observation (B) of Minute 308 noted that Mexico "intended to finance the modernization and technical enhancement for sustainability in irrigated areas." Minute 308, supra note 67, at 3. Observation (C) of the same noted that Mexico planned to make a capital investment of 1.5 billion pesos in the next four years for improved hydraulic efficiency. Id.

269. "The Government of the United States and the Government of Mexico will urge the appropriate international funding institutions, to which they are a party, to ensure analyses and consideration of the Commission's observations concerning the water conservation projects" cited earlier. Minute 308, supra note 67, at 4. One of these institutions is the North American Development Bank (NADBANK), to which the United States and Mexico have made capital investments of over $\$ 300$ million. Nitze, supra note 7 , at 10 . Recently, NADBANK has begun financing water conservation projects in the border region and is considering assisting Texas irrigators in funding improvements in irrigation efficiency, while also planning to do the same on the Mexican side of the border. Id. at 12.

Most recently, the two sides have begun in earnest to implement water-saving technology. Minute 309 is the IBWC response to its own mandate of Minute 308 to find ways to conserve water through hydraulic infrastructure improvements and modernization. See Minute 309: Volumes of Water Saved with the Modernization and Improved Technology Projects for the Irrigation Districts in the Rio Conchos Basin and Measures for their Conveyance to the Rio Grande, July 7, 2003, U.S.-Mex., at http://www.ibwc.state.gov/ html/body_ minutes.HTM (last visited Nov. 12, 2003). According to the terms of the new Minute, Mexico agrees to complete the infrastructure improvements (in the Rio Conchos Basin's three irrigation districts) by 2006. Mexico estimates an eventual water savings of 321,043af (based on a premodernization average release of $846,385 \mathrm{af}$ ). These improvements are predicated upon Mexico's obtaining the $\$ 1.5$ billion pesos necessary for construction and related costs. Once the improvements have been put into effect, the saved amounts of water will be transferred every January to the Rio Grande, where they will be used to meet Mexico's article 4 obligation, including any accrued debt. Id. at 5-6. 
is that positive results will not be seen for some years to come; therefore, a debt payment schedule sedulously followed by Mexico would do much to keep Texas users satisfied until the contemplated projects bear fruit.

\section{CONCLUSION}

In his statement before the U.S. Senate Foreign Relations Committee, Oscar C. Dancy, County Judge of Cameron County, Texas, urged the ratification of the water treaty in words that riveted his listeners:

We ask-we pray, that you approve this treaty and remove this sword of Damocles which is dangling over our heads. Pass this treaty, and let us make this Rio Grande become, not a dividing line but a uniting bond and channel of friendship and cooperation between our two great nations, that will be an example for all other nations, and be the first step in making the good-neighbor policy the national policy for every nation on this globe. Let us adopt that righteousness that exalteth a nation. Then, and not till then, will the vision of the Prophet Isaiah be realized ... 'And he shall judge among the nations, and shall rebuke many people; and they shall beat their swords into plowshares, and their spears into

The 321,043af of savings will come from canal lining, low-pressure water supply systems, land-leveling to reduce gravity flow irrigation losses, and improved pumping stations. Id. at 3.

What appears to be a substantial advance in Anglo-Mexican water diplomacy may really be a mere baby step, as Mexico has reserved several legal "outs" from its newly-crafted water savings obligation. First, Mexico's obligation is dependent upon the accumulation of the necessary funds-if it cannot find the money, it need do nothing. Id. at 5-6. Second, when the volume of water released to the irrigation districts is less than the base amount of 846,385af, the required savings obligation will be proportionately reduced. Id. at 6 (analogous to the American escape clause in article 10). Third, Mexico will retain legal authority over all the saved water until it is delivered to the Rio Grande. Id.

It is not clear, however, whether Mexico is still obligated to transfer the "saved" amount if consumptive uses in the Mexican irrigation districts increase; for then the "saved" water will have been consumed. Were this to occur, the United States would likely have little recourse besides that which it has already pursued with respect to Mexico's article 4 debt. The United States' options are limited simply because the saved water, by the Minute's express terms, remains under Mexican ownership until it reaches the Rio Grande. Therefore, the United States can have no claim of conversion against Mexico; instead it may seek specific performance of this particular savings obligation.

These criticisms are not meant to disparage what is an essential first attempt toward aggressive modernization and concomitant water savings in the Rio Grande Basin to fulfill Mexico's article 4 obligation. Indeed, conservation is the ultimate and best answer to the Mexican debt problem. 
pruning hooks: nation shall not lift sword against nation, neither shall they learn war any more. ${ }^{270}$

In that spirit, both sides must now consider their options for resolving the controversy over Mexico's water debt to the United States. One option is treaty renegotiation, a possibility that becomes less enchanting to either side the closer it is scrutinized. Another option is for the United States to wrestle another partial payment from Mexico to placate south Texas, and then put off further action until conservation and efficiency improvement measures in Mexico yield results. But the best answer is for both sides to arrive at a final and definitive solution, under the aegis of the $\mathrm{BBWC}$, which adopts the elements listed above. Barring that, there remains one further option: in the words of a Chihuahuense farmer, "Pray to San Isidro" to make it rain. ${ }^{271}$

\section{NafuralResources Weblinks}

http:/www.law.du.edu/naturalresources/weblinks.htm

This website offers free access to a broad range of specialized topics and country specific information covering the field of foreign and domestic natural resources law. Created at the University of Denver College of Law, topics include:

$\begin{array}{llll}\text { Energy } & \text { Environment } & \text { Forestry } & \text { Investment } \\ \text { Mining } & \text { Oil \& Gas } & \text { Indigenous Peoples } & \text { Treaties } \\ \text { Land Use } & \text { Taxation } & \text { Sustainable Development } & \text { Water }\end{array}$

Individual pages for approximately 140 countries provide links to legislation, legal databases, government agencies, search engines and background data. 